Review

\title{
Molecular Targeted Drugs and Biomarkers in NSCLC, the Evolving Role of Individualized Therapy
}

\author{
Kalliopi Domvri1, Paul Zarogoulidis ${ }^{1,2}{ }^{\bowtie}$, Kaid Darwiche², Robert F. Browning 3 , Qiang Li', J. Francis \\ Turner ${ }^{5}$, Ioannis Kioumis ${ }^{1}$, Dionysios Spyratos ${ }^{1}$, Konstantinos Porpodis ${ }^{1}$, Antonis Papaiwannou ${ }^{1}$, Theo- \\ dora Tsiouda ${ }^{6}$, Lutz Freitag ${ }^{2}$, Konstantinos Zarogoulidis ${ }^{1}$ \\ 1. Pulmonary Department-Oncology Unit, "G. Papanikolaou“ General Hospital, Aristotle University of Thessaloniki, Thessaloniki, Greece \\ 2. Department of Interventional Pneumology, Ruhrlandklinik, West German Lung Center, University Hospital, University Duis- \\ burg-Essen, Essen \\ 3. Pulmonary \& Critical Care Medicine, Interventional Pulmonology, National Naval Medical Center, Walter Reed Army Medical Center, \\ Bethesda, U.S.A \\ 4. Department of Respiratory Diseases, Changhai Hospital/First Affiliated Hospital of the Second Military Medical University, Shanghai, \\ China \\ 5. Pulmonary Medicine, University of Nevada School of Medicine, National Supercomputing Center for Energy and the Environment \\ University of Nevada, Las Vegas, U.S.A \\ 6. Internal Medicine Unit, "Theiageneio" Anticancer Hospital, Thessaloniki, Greece
}

$\triangle$ Corresponding author: Paul Zarogoulidis, M.D, Ph.D, Pulmonary Department-Oncology Unit, "G. Papanikolaou" General Hospital, Aristotle University of Thessaloniki, Thessaloniki, Greece. Tel: 00302310992433; Fax: 00302310992432; E-mail: kzarogoy@auth.gr

(c) Ivyspring International Publisher. This is an open-access article distributed under the terms of the Creative Commons License (http://creativecommons.org/ licenses/by-nc-nd/3.0/). Reproduction is permitted for personal, noncommercial use, provided that the article is in whole, unmodified, and properly cited.

Received: 2013.09.23; Accepted: 20 I3.I I.I2; Published: 2013.II.23

\begin{abstract}
Lung cancer first line treatment has been directed from the non-specific cytotoxic doublet chemotherapy to the molecular targeted. The major limitation of the targeted therapies still remains the small number of patients positive to gene mutations. Furthermore, the differentiation between second line and maintenance therapy has not been fully clarified and differs in the clinical practice between cancer centers. The authors present a segregation between maintenance treatment and second line and present a possible definition for the term "maintenance" treatment. In addition, cancer cell evolution induces mutations and therefore either targeted therapies or non-specific chemotherapy drugs in many patients become ineffective. In the present work pathways such as epidermal growth factor, anaplastic lymphoma kinase, met proto-oncogene and $\mathrm{PI} 3 \mathrm{~K}$ are extensively presented and correlated with current chemotherapy treatment. Future, perspectives for targeted treatment are presented based on the current publications and ongoing clinical trials.
\end{abstract}

Key words: NSCLC, pathways, targeted treatment, maintenance

\section{Background}

Although cancer therapeutics has achieved several advances in the treatment of lung cancer patients, lung cancer remains the leading cause of cancer-related mortality. Lung cancers are divided into two histological groups: Non-Small Cell lung Cancers (NSCLC) and Small Cell Lung Cancer (SCLC). In addition, $85 \%$ of all lung cancers are categorized as NSCLC [1] which is further subdivided into adeno- carcinoma, squamous cell carcinoma and large cell carcinoma, roughly accounting for almost $80 \%$ of the lung tumors [2]. Although lung cancer has been epidemiologically associated largely with cigarette smoking [3], lifestyle, diet, passive smoking, and occupational exposure have also been found to play contributory roles [4-7].

Disease stage determines the treatment of 
NSCLC which includes surgery, radiation, platinum-based doublet chemotherapy and recently targeted therapies by interrupting signaling pathways responsible for cell proliferation and survival. Earlier stages of the disease benefit from systemic chemotherapy, which is also therapeutic strategy for stages II and III of NSCLC [8-10]. Besides, early-stage and localized disease treatment are still maintained by surgery. Moreover, according to some studies, palliative chemotherapy or radiation therapy has shown improvements in survival and quality of life measures in patients with advanced and metastatic disease [11, 12]. In general, classical chemotherapy (platinum-doublet, taxanes, gemcitabine, pemetrexed) results in modest efficacy, thus, multimodal therapeutic strategy has become an important treating option for NSCLC patients. In several studies, two or more drug combinations were proven to have superior efficacy but at the expense of added toxicity [13, 14].

Recently, according to the National Cancer Institute Office of Cancer Genomics, enhancement of the understanding of the molecular mechanisms of cancer, acceleration of genomic science and technology development and translation of genomic data to improve cancer prevention, early detection, diagnosis, and treatment are the goals established for the facilitation of personalized cancer medicine [15].

Additionally, until recently the most effective targeted drugs in the management of NSCLC include the epidermal growth factor receptor (EGFR) and the angiogenesis pathway [16]. Erlotinib which targets the EGFR and crizotinib which targets EML4/ALK molecular pathway are the only agents currently approved in the United States as third-line therapy for patients with advanced/metastatic NSCLC [17]. Furthermore, according to Azzoli et al immediate treatment with an alternative single-agent chemotherapy such as pemetrexed in patients with nonsquamous histology, docetaxel in unselected patients, or erlotinib in unselected patients might be considered for NSCLC patients with stable disease or response after four cycles [18]. Among the targeted agents that have undergone evaluation for third-line therapy and beyond are afatinib, apatinib, axitinib, AUY922, pazopanib, sorafenib, sunitinib, and vandetanib [17].

The last decade clinical research is strongly occupied with the identification of mutations and aberrations concerning NSCLC molecular pathways which has enabled a personalized medicine approach to treatment [19]. According to The National Institute of Health (NIH) a biomarker is defined as a characteristic that is objectively measured and evaluated as an indicator of normal biologic processes, pathogenic processes, or pharmacologic responses to a therapeu- tic intervention [20].

Thus, recent studies have focused their efforts into incorporating tumor genotyping into clinical decision-making. To date, molecular biomarkers such as EGFR, is included as standard care for NSCLC patients and K-ras mutations include an emerging tool in NSCLC therapy [21, 22]. Besides, currently large-scale testing for somatic alterations in proto-oncogene B-Raf (BRAF), phosphatidylinositol-4,5-bisphosphate 3-kinase, catalytic subunit alpha (PIK3CA), human epidermal growth factor receptor 2 (HER2), and anaplastic lymphoma kinase (ALK) is also feasible and impacts therapeutic decisions [23]. As far as gene expression in NSCLC is concerned, the association between COX-2 or p53 overexpression and survival in lung cancer patients has not yet reached a satisfactory clinical interest [24, 25].

Moreover, customizing chemotherapy by histological subtype has been included in researchers' practice such as pemetrexed for nonsquamous tumors [26] or the addition of a monoclonal antibody to the chemotherapy such as bevacizumab $[22,26]$ and cetuximab [27].

Despite the development of new chemotherapeutics, NSCLC still has a 5-year survival rate in only $14 \%$ implying the need for the continuing research for novel treatments [28]. In the present review, we are focusing on the ongoing research concerning the treatment of NSCLC patients in clinical trials, including the elucidation of molecular biomarkers and the introduction of novel molecular targeted drugs which are being evaluated as monotherapy or in combination with other treatments.

\section{Molecular pathways and targeted therapies}

\section{Targeting epidermal growth factor receptor (EGFR)}

EGFR family a tyrosine kinase receptor, (also known as HER or ErbB family) includes four members: epidermal growth factor receptor (EGFR) or HER1/ErbB1, HER2/ErbB2, HER3/ErbB3, HER4/ErbB4. This EGFR family activates two major downstream intracellular pathways in solid tumors, the RAS/RAF/MEK/MARK and the PI3K/AKT/ mTOR pathway, which induce cancer cell proliferation, cell growth, invasion, metastatic spread, apoptosis, and tumor angiogenesis [29]. EGFR overexpression is found in approximately $40 \%-80 \%$ of the NSCLC patients [1] and has been associated with poor prognosis [30]. Thus, EGFR signaling is the most intensively studied of the four family members and one of the major targets of NSCLC treatment. (Figure 1,2) (Table 1) 


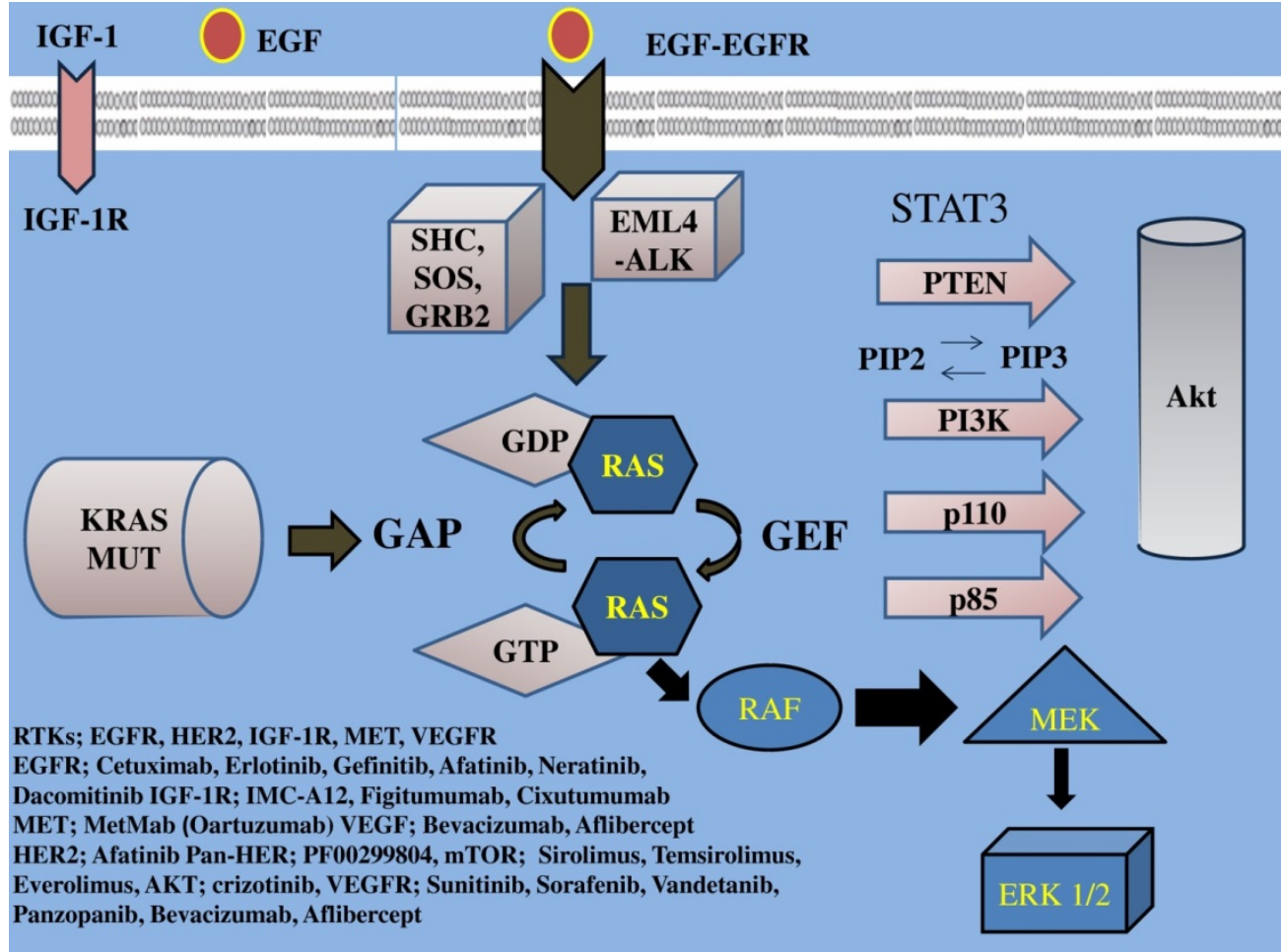

Figure I. IGF-I; insulin growth factor-I, IGF-IR; insulin growth factor receptor-I, EGF; epidermal growth factor, EGFR; epidermal growth factor receptor, VEGF; vascular endothelial growth factor, VEGFR; vascular endothelial growth factor receptor, PI3K; phosphatidylinositide 3-kinase, PTEN; phosphatase and tensin homologue, SHC; Src homology/collagen, SOS; son of sevenless, GRB2; growth factor receptor-bound protein 2, GAP; GTPase activating protein, GDP; guanosine diphosphate, GEF; guanine nucleotide exchange factors, EML4-ALK; echinoderm microtubule-associated protein-like 4 fused with the anaplastic lymphoma kinase, ERK; extracellular signal-regulated kinases, GTP; guanosine trisphate, MEK; mitogen-activated protein kinase, RAF; proto-oncogene serine/threonine-protein kinase, PIP2; phosphatidylinositol 4,5-bisphosphate, PIP3; phosphatidylinositol 3,4,5-triphosphate, RAS; Rat sarcoma, HER2; Human Epidermal Growth Factor Receptor 2. Activation of the growth factors to transmembrane tyrosine kinase receptors finally increases cell growth, proliferation, metabolism and survival.

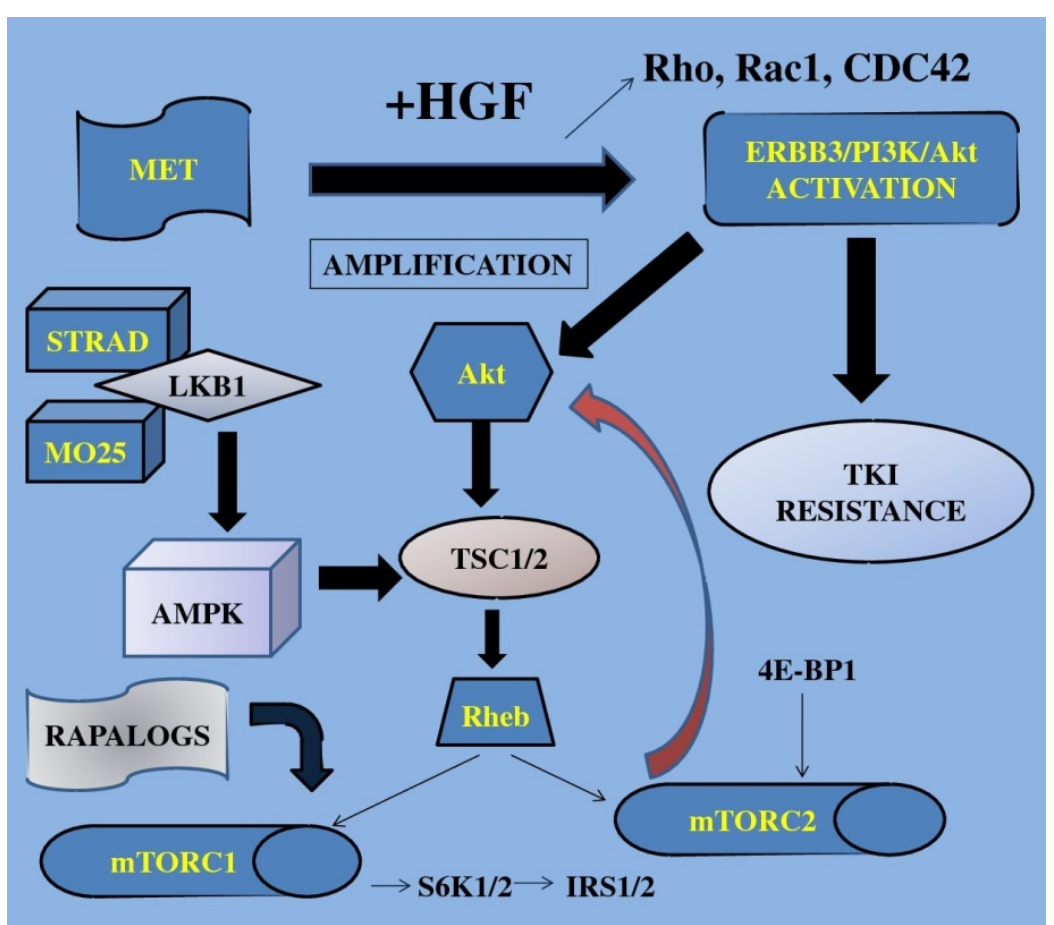

Figure 2. TKI; tyrosine kinase inhibitors, S6KI; 40S ribosomal protein S6 kinase, IRS I/2; insulin receptor substrate, 4E-BP I; 4E binding protein-I, Akt; protein kinase B, mTOR; mammalian target of rapamycin, STRAD; Ste20-like adaptor protein, TSC; tuberous sclerosis complex, AMPK; adenosine mono-phosphate-activated protein kinase, LKB I; liver kinase BI, HGF; hepatocyte growth factor, MET; mesenchymal-epithelial transition factor, Rho; RAS homolog gene family, Racl; RAS-related C3 botulinum toxin substrate I, CDC42; cell division cycle 42, Rheb; Ras homolog enriched in brain, MO25; monoclonal antibody, ERBB3; v-erb-b2 erythroblastic leukemia viral oncogene homolog 3. Growth factors when activated trigger the mTOR-signaling pathway finally resulting in increased cell growth, gene transcription and cell proliferation. 
Table I. Targeted therapies

\begin{tabular}{|c|c|c|c|c|c|c|c|c|c|c|c|}
\hline $\begin{array}{l}\text { First name } \\
\text { STUDY }\end{array}$ & $\begin{array}{l}\text { Primary End- } \\
\text { point/objective }\end{array}$ & $\mathbf{n}$ & $\begin{array}{l}\text { PLACE OF } \\
\text { STUDY }\end{array}$ & $\begin{array}{l}\text { PHASE/ } \\
\text { Programme }\end{array}$ & $\begin{array}{l}\text { STAGE OF } \\
\text { NSCLC }\end{array}$ & TREATMENT & $\begin{array}{l}\text { EGFR } \\
\text { posi- } \\
\text { tive }\end{array}$ & $\begin{array}{l}\text { PATIENTS } \\
\text { pre-treatment }\end{array}$ & $\begin{array}{l}\text { OBJECTI } \\
\text { VE } \\
\text { RESPON } \\
\text { SE RATE } \\
\text { (ORR) } \\
\%\end{array}$ & $\begin{array}{l}\text { MEDIAN } \\
\text { OVERAL } \\
\text { L } \\
\text { SURVIV } \\
\text { AL (OS) }\end{array}$ & $\begin{array}{l}\text { MEDIAN } \\
\text { PROGRESSI } \\
\text { ON -FREE } \\
\text { SURVIVAL } \\
\text { (PFS) }\end{array}$ \\
\hline Kris et al 2003 & $\begin{array}{l}\text { symptomatic } \\
\text { and radio- } \\
\text { graphic re- } \\
\text { sponse }\end{array}$ & 221 & USA & II & IIIB or IV & gefitinib & No & $\begin{array}{l}\text { Pretreated/ platinum- } \\
\text { or taxane-based CT }\end{array}$ & 22 & $6-7$ & - \\
\hline Simon et al 2003 & OS & 183 & USA & $\begin{array}{l}\text { prospec- } \\
\text { tive land- } \\
\text { mark } \\
\text { analysis }\end{array}$ & advanced & gefitinib & No & Pretreated & 3.8 & 8.8 & 3.6 \\
\hline $\begin{array}{l}\text { Gaafar et al } 2011 \\
\text { (EORTC study } \\
08021 / \text { ILCP 01/03) }\end{array}$ & OS & 173 & Egypt & III & advanced & gefitinib & No & $\begin{array}{l}\text { Pretreat- } \\
\text { ed/platinum-based } \\
\text { CT }\end{array}$ & - & 10.9 & 4.1 \\
\hline Wang et al 2006 & OS & 151 & China & $\begin{array}{l}\text { Expanded } \\
\text { Access } \\
\text { Pro- } \\
\text { gramme }\end{array}$ & IIIb or IV & gefitinib & No & $\begin{array}{l}\text { Pretreated/ platinum- } \\
\text { or taxane-based CT }\end{array}$ & 29.8 & 15.3 & 12.0 \\
\hline $\begin{array}{l}\text { Fukuoka et al } 2003 \\
\text { (The IDEAL } 1 \text { Trial) }\end{array}$ & $\begin{array}{l}\text { efficacy and } \\
\text { tolerability of } \\
\text { two doses }\end{array}$ & 210 & Japan & II & advanced NSCLC & Gefitinib (250-mg) & No & $\begin{array}{l}\text { Pretreated/platinum- } \\
\text { or taxane-based CT }\end{array}$ & 18.4 & 8.0 & 2.8 \\
\hline $\begin{array}{l}\text { Thatcher et al } 2005 \\
\text { ISEL }\end{array}$ & OS & $\begin{array}{l}169 \\
2\end{array}$ & UK & III & IIIB or IV & gefitinib & No & $\begin{array}{l}\text { pretreated/platinum- } \\
\text { or taxane-based CT }\end{array}$ & - & 5.6 & 3 \\
\hline $\begin{array}{l}\text { Giaccone et al } 2004 \\
\text { (INTACT 1) }\end{array}$ & OS & $\begin{array}{l}109 \\
3\end{array}$ & $\begin{array}{l}\text { The Neth- } \\
\text { erlands }\end{array}$ & III & III or IV & $\begin{array}{l}\text { Gefitinib + gemcita- } \\
\text { bine and cisplatin }\end{array}$ & No & untreated & 49.7 & 9.9 & 5.5 \\
\hline $\begin{array}{l}\text { Herbst et al } 2004 \\
\text { (INTACT 2) }\end{array}$ & OS & $\begin{array}{l}103 \\
7\end{array}$ & USA & III & III or IV & $\begin{array}{l}\text { Gefitinib + paclitaxel } \\
\text { and carboplatin }\end{array}$ & No & untreated & & 8.7 & \\
\hline $\begin{array}{l}\text { Mitsudomi et al } \\
2010 \text { (WJTOG3405) }\end{array}$ & PFS & 177 & Japan & III & III or IV & $\begin{array}{l}\text { Gefitinib vs cisplatin } \\
\text { and docetaxel }\end{array}$ & Yes & untreated & 62.1 & 30.9 & 9.2 \\
\hline $\begin{array}{l}\text { Fukuoka et al } 2011 \\
\text { (IPAS) }\end{array}$ & OS & $\begin{array}{l}121 \\
7\end{array}$ & Japan & III & III or IV & $\begin{array}{l}\text { gefitinib vs car- } \\
\text { boplatin/ paclitaxel }\end{array}$ & Yes & untreated & 43 & 18.8 & 5.7 \\
\hline Mok et al 2009 & PFS & 609 & Asia & III & III or IV & gefitinib & Yes & untreated & 71.2 & 18.6 & 5.7 \\
\hline $\begin{array}{l}\text { Maemondo et al } \\
2010\end{array}$ & PFS & 230 & Japan & - & III or IV & $\begin{array}{l}\text { gefitinib or car- } \\
\text { boplatin-paclitaxel. }\end{array}$ & Yes & untreated & 73.7 & 30.5 & 10.8 \\
\hline $\begin{array}{l}\text { Shepherd et al } 2005 \\
\text { (BR21) }\end{array}$ & OS & 731 & Canada & III & IIIB or IV & erlotinib & No & pretreated & 8.9 & 6.7 & 2.2 \\
\hline $\begin{array}{l}\text { Zhou et al } 2011 \\
\text { (OPTIMAL, CTON } \\
\text { G-0802) }\end{array}$ & PFS & 154 & China & III & IIIB or IV & $\begin{array}{l}\text { erlotinib vs gemcita- } \\
\text { bine plus carboplatin }\end{array}$ & Yes & untreated & 83 & - & 13.1 \\
\hline $\begin{array}{l}\text { Rosell et al } 2012 \\
\text { (EURTAC) }\end{array}$ & PFS & 174 & Europe & III & $\begin{array}{l}\text { Advanced } \\
\text { NSCLC }\end{array}$ & $\begin{array}{l}\text { erlotinib vs plati- } \\
\text { num-based CT }\end{array}$ & Yes & untreated & 54.4 & 22.9 & 9.4 \\
\hline Pallis et al 2012 & PFS & 49 & Greece & II & IIIB/IV & erlotinib & No & untreated & 24.5 & 15.5 & 6.7 \\
\hline $\begin{array}{l}\text { Ramalingam et al } \\
2012\end{array}$ & PFS & 188 & USA & II & advanced & $\begin{array}{l}\text { erlotinib vs } \\
\text { dacomitinib }\end{array}$ & Yes & pretreated & - & 7.44 & 1.91 \\
\hline $\begin{array}{l}\text { Cufer et al } 2006 \\
(\text { SIGN) }\end{array}$ & $\begin{array}{l}\text { assessment of } \\
\text { symptom } \\
\text { improvement }\end{array}$ & 141 & Slovenia & II & advanced NSCLC & $\begin{array}{l}\text { gefitinib vs docet- } \\
\text { axel }\end{array}$ & No & $\begin{array}{l}\text { pretreated/platinum- } \\
\text { or taxane-based }\end{array}$ & 13.2 & 7.5 & 3.0 \\
\hline $\begin{array}{l}\text { Miller et al } 2012 \\
\text { (LUX-Lung 1) }\end{array}$ & OS & 697 & USA & $\mathrm{IIb} / \mathrm{III}$ & IIIB or IV & afatinib & Yes & pretreated & - & 10.8 & 3.3 \\
\hline $\begin{array}{l}\text { Yang et al } 2012 \\
\text { (LUX-Lung 2) }\end{array}$ & ORR & 129 & Taiwan & II & $\begin{array}{l}\text { stage IIIb with } \\
\text { pleural effusion or } \\
\text { stage } \\
\text { IV/adenocarcino } \\
\text { ma }\end{array}$ & afatinib & Yes & $\begin{array}{l}\text { Pretreated platinum- } \\
\text { or taxane-based }\end{array}$ & 61 & 24.8 & 10.1 \\
\hline $\begin{array}{l}\text { Sequist et al } \\
2013 \text { (LUX-Lung 3) }\end{array}$ & PFS & $\begin{array}{l}126 \\
9\end{array}$ & - & III & $\begin{array}{l}\text { IIIB/IV lung } \\
\text { adenocarcinoma }\end{array}$ & afatinib & yes & untreated & - & - & 11.1 \\
\hline Sequist et al 2010 & ORR & 167 & USA & II & advanced & neratinib & Yes & pretreated & 54 & - & 15.3weeks \\
\hline Butts et al 2007 & RR & 131 & Canada & II & IIIB / IV & cetuximab & No & $\begin{array}{l}\text { pretreated gemcita- } \\
\text { bine/platinum }\end{array}$ & 27.7 & 11.99 & 5.09 \\
\hline Rosell et al 2008 & $\begin{array}{l}\text { activity, safety } \\
\text { and pharma- } \\
\text { cokinetics }\end{array}$ & 86 & Spain & II & advanced & cetuximab & Yes & $\begin{array}{l}\text { pretreated cisplatin } \\
\text { and vinorelbine }\end{array}$ & 38 & 8.3 & 5.0 \\
\hline $\begin{array}{l}\text { Lynch et al } 2010 \\
\text { (BMS099) }\end{array}$ & PFS & 676 & USA & III & IIIB / IV & cetuximab & No & $\begin{array}{l}\text { Pretreated tax- } \\
\text { ane/carboplatin }\end{array}$ & $25.7 \%$ & 9.69 & 4.40 \\
\hline $\begin{array}{l}\text { Pirker et al } 2009 \\
\text { (FLEX) }\end{array}$ & OS & $\begin{array}{l}112 \\
5\end{array}$ & Austria & III & IIIB / IV & cetuximab & No & $\begin{array}{l}\text { pretreated cisplatin } \\
\text { and vinorelbine }\end{array}$ & - & 11.3 & 4.8 \\
\hline Hanna et al 2006 & RR & 66 & USA & II & advanced & cetuximab & Yes & $\begin{array}{l}\text { Pretreated tax- } \\
\text { ane/carboplatin }\end{array}$ & $5 \%$ & 8.9 & 2.3 \\
\hline $\begin{array}{l}\text { Ramalingam et al } \\
2011\end{array}$ & 12-week PFS & 172 & USA & II & advanced & $\begin{array}{l}\text { Erlotinib + R1507 } 16 \\
\mathrm{mg} / \mathrm{kg}\end{array}$ & No & $\begin{array}{l}\text { Pretreated/ tax- } \\
\text { ane/carboplatin }\end{array}$ & - & 12.1 & $44 \%$ \\
\hline
\end{tabular}




\begin{tabular}{|c|c|c|c|c|c|c|c|c|c|c|c|}
\hline $\begin{array}{l}\text { Maruyama et al } \\
2010 \text { V-15-32 }\end{array}$ & OS & 489 & Japan & III & $\begin{array}{l}\text { ad- } \\
\text { vanced/metastati } \\
\text { c }\end{array}$ & $\begin{array}{l}\text { gefitinib versus } \\
\text { docetaxel }\end{array}$ & No & $\begin{array}{l}\text { Pretreated/ tax- } \\
\text { ane/carboplatin }\end{array}$ & 22.5 & - & 2 \\
\hline Lee et al 2010 & PFS & 161 & Korea & III & $\begin{array}{l}\text { ad- } \\
\text { vanced/metastati } \\
\text { c }\end{array}$ & $\begin{array}{l}\text { gefitinib versus } \\
\text { docetaxel }\end{array}$ & No & $\begin{array}{l}\text { Pretreated plati- } \\
\text { num-based CT }\end{array}$ & $28.1 \%$ & - & - \\
\hline $\begin{array}{l}\text { Kim et al } 2008 \\
\text { (INTEREST) }\end{array}$ & OS & $\begin{array}{l}146 \\
6\end{array}$ & USA & III & advanced & $\begin{array}{l}\text { gefitinib versus } \\
\text { docetaxel }\end{array}$ & No & $\begin{array}{l}\text { Pretreated plati- } \\
\text { num-based regimen }\end{array}$ & 9.1 & 7.6 & 2.2 \\
\hline $\begin{array}{l}\text { Herbst et al } 2005 \\
\text { TRIBUTE }\end{array}$ & OS & $\begin{array}{l}105 \\
9\end{array}$ & USA & III & IIIB/IV & $\begin{array}{l}\text { erlotinib + car- } \\
\text { boplatin and paclita } \\
\text { xel }\end{array}$ & No & untreated & 21.5 & 10.6 & - \\
\hline \multirow[t]{2}{*}{$\begin{array}{l}\text { Wheatley-Price et } \\
\text { al } 2008 \text { BR21 }\end{array}$} & $\begin{array}{l}\text { PFS, OS, RR, } \\
\text { QOL }\end{array}$ & 731 & Canada & III & advanced & erlotinib & No & $\begin{array}{l}\text { Elderly pretreated } 1^{\text {st }} \\
\text { line }\end{array}$ & 8.9 & 6.7 & 2.2 \\
\hline & & & & & & VEGF & & & & & \\
\hline $\begin{array}{l}\text { LeCaer et al } \\
\text { (GFPC 0505) }\end{array}$ & TTP2 & 100 & France & II & IIIB/IV & $\begin{array}{l}\text { gemcita- } \\
\text { bine }(G) \text { followed by } \\
\text { erlotinib }\end{array}$ & No & Untreated/elderly & 13.6 & 4.4 & - \\
\hline $\begin{array}{l}\text { Niho et al } 2012 \\
\text { (JO19907) }\end{array}$ & PFS & 180 & Japan & II & $\begin{array}{l}\text { IIIB, IV or recur- } \\
\text { rent- } \\
\text { non-squamous }\end{array}$ & bevacizumab & No & $\begin{array}{l}\text { Pretreated car- } \\
\text { boplatin-paclitaxel }\end{array}$ & 60.7 & 22 & - \\
\hline $\begin{array}{l}\text { Reck et al } 2009 \\
\text { (AVAIL) }\end{array}$ & OS to PFS & $\begin{array}{l}104 \\
3\end{array}$ & Germany. & III & $\begin{array}{l}\text { ad- } \\
\text { vanced nonsquam } \\
\text { ous }\end{array}$ & bevacizumab & No & $\begin{array}{l}\text { Pretreated cispla- } \\
\text { tin/gemcitabine }\end{array}$ & 30.4 & 6.7 & 13.6 \\
\hline $\begin{array}{l}\text { Takeda et al } 2012 \\
\text { (WJOG 5910L) }\end{array}$ & PFS & & Japan & II & $\begin{array}{l}\text { advanced } \\
\text { nonsquamous }\end{array}$ & bevacizumab & No & $\begin{array}{l}\text { Pretreated } 1 \text { st line } \\
\text { bevacizumab +a } \\
\text { platinum-based } \\
\text { doublet }\end{array}$ & 40 & 13.0 & 5.6 \\
\hline Heymach et al 2007 & PFS & 127 & USA & II & IIIB/IV & $\begin{array}{l}\text { vandetanib plus } \\
\text { docetaxel }\end{array}$ & No & $\begin{array}{l}\text { Pretreated } 1^{\text {st }} \text { line } \\
\text { platinum-based CT }\end{array}$ & 32 & - & 11.5 \\
\hline de Boer et al 2011 & PFS & 534 & Australia & III & advanced & $\begin{array}{l}\text { vandetanib plus } \\
\text { pemetrexed }\end{array}$ & No & $\begin{array}{l}\text { Pretreated-failure } 1^{\text {st }} \\
\text { line treatment }\end{array}$ & 19 & 10.5 & 17.6 \\
\hline $\begin{array}{l}\text { Lee et al } 2012 \\
\text { (ZEPHYR) }\end{array}$ & OS & 924 & Korea & III & advanced & Vandetanib & No & $\begin{array}{l}\text { Pretreated-treatment } \\
\text { failure with an EGFR } \\
\text { TKI }\end{array}$ & 2.6 & 8.5 & 1.9 \\
\hline
\end{tabular}

More specifically, one strategy for the inhibition of EGFR includes EGFR tyrosine kinase inhibitors (TKIs) which target the intracellular tyrosine kinase (TK) domain of EGFR, blocking the downstream signaling of the receptor [31].

EGFR inhibitors include small molecule tyrosine kinase inhibitors (TKIs) such as gefitinib, erlotinib and afatinib and monoclonal antibodies such as cetuximab which have been studied in phase III trials and are currently clinically being used in NSCLC patients. Among these EGFR inhibitors, only erlotinib has been approved in many countries as second-line therapy for advanced NSCLC patients [32]. To date, gefitinib (ZD1839; Iressa) and erlotinib (OSI-774; Tarceva) are the most studied of the EGFR TKIs for the treatment of NSCLC.

Several phase II trials [33] [34, 35] or phase III trials [36] have favored gefitinib in pretreated patients and even as first line treatment. Indeed, since 2005 several studies included gefitinib monotherapy as first line treatment in untreated NSCLC patients with some efficacy [37-41] or limited results due to interstitial lung disease (ILD) an adverse effect [42, 43]. Although the most common adverse events are skin rash and diarrhea, ILD is a more serious co-morbidity of NSCLC associated with gefitinib and other cancer treatments. ILD-type events that were more common in Asian patients, appeared in overall incidence of approximately $1 \%$ in gefitinib recipients participating in clinical trials [44].

A Double-blind, randomized phase II trial conducted from November 2000 to April 2001 in 30 US academic and community oncology centers enrolled 221 patients with either stage IIIB or IV NSCLC for which they had received at least two chemotherapy regimens before gefitinib with results favoring gefitinib [33]. In a single-center experience, reported by Simon et al 2003, $(\mathrm{N}=183)$ gefitinib demonstrated clinically significant antitumor activity and provided good palliation in a predominantly pretreated group of patients [34]. In another randomized, double-blind, parallel-group, multicenter phase II trial $(\mathrm{N}=210)$, NSCLC patients who were previously treated with one or two chemotherapy regimens (at least one containing platinum) were randomly assigned to receive either 250-mg or 500-mg oral doses of gefitinib once daily, showing clinically meaningful antitumor activity [35].

However, the Iressa Survival Evaluation in Lung Cancer (ISEL), a placebo-controlled phase III study which investigated the effect on survival of gefitinib as second-line or third-line treatment for patients with locally advanced or metastatic NSCLC $(\mathrm{N}=1692)$ showed disappointing results [45]. Because of this trial's results, even though gefitinib was the first TKI to be approved in 2003 for the third-line treatment of 
NSCLC, two years later the US FDA allowed its use only within clinical trials or to patients who had already received a clinical benefit.

Furthermore, in phase III trials INTACT 1 and 2 gefitinib either in combination with gemcitabine and cisplatin in chemotherapy-naive patients with advanced NSCLC did not have improved efficacy over gemcitabine and cisplatin alone [46] or in combination with paclitaxel and carboplatin showed any added benefit in survival, time to progression (TTP) or response rate (RR), when compared with standard chemotherapy alone [47].

Overall, gefitinib therapy has not shown the expected response to unselected patients. Recently several research groups identified EGFR gene mutations as predictive factors for drug sensitivity [48-51]. EGFR mutations have been identified in larger numbers in Asians, women, non-smokers, and patients with adenocarcinoma, groups. It is a fact that, after the Iressa Pan-Asia Study trial (IPAS), based on progression free survival (PFS) results, gefitinib was approved for the treatment of NSCLC with certain EGFR mutations in all lines of therapy identifying the highly gefitinib-sensitive clinical subset [52].

These mutations lead to increased growth factor signaling and confer susceptibility to the inhibitor. Screening for such mutations in lung cancers identifies patients who will have a clinical responsiveness to gefitinib [48, 53]. Since the existence of EGFR gene mutations (exon 19 deletions or the exon 21 L858R) were reported as a predictive factor for sensitivity to EGFR-TKIs, several studies based their research on this conclusion [54, 55]. Indeed, a lot of studies concluded that gefitinib was superior to carboplatinpaclitaxel [56-58] or cisplatin-docetaxel [51, 52] as an initial treatment, that improved PFS and that the presence in the tumor of a mutation of the EGFR gene was a strong predictor of a better outcome with gefitinib.

As for erlotinib, it was approved by FDA in 2004, based on the results of the BR21 trial, a phase III international, randmized, double-blind, placebo-controlled trial that compared erlotinib (150 mg daily) plus best supportive care (BSC) with BSC alone in second- and third-line settings in 731 unselected patients with no EGFR mutation testing concluded [21].

Erlotinib as first line treatment when compared with chemotherapy improved Quality of life (QoL) [59] and conferred a significant PFS [60] not only in Chinese patients with advanced EGFR mutationpositive NSCLC in OPTIMAL (CTONG-0802), an open-label, randomized phase III trial, but also in European patients in EURTAC, another multicentre, open-label, randomized phase 3 trial [61]. More spe- cifically, in EURTAC trial (NCT00446225) erlotinib was compared with standard chemotherapy for first-line treatment of European patients $(\mathrm{N}=174)$ with advanced EGFR-mutation positive NSCLC [61]. Patients received oral erlotinib per day or 3 week cycles of standard intravenous chemotherapy of cisplatin on day 1 plus docetaxel or gemcitabine on days 1 and 8 . Their findings strengthened the rationale for routine baseline tissue-based assessment of EGFR mutations in patients with NSCLC and for treatment of mutation-positive patients with EGFR tyrosine-kinase inhibitors.

Besides, in recent phase II clinical trials it was suggested that the use of clinical (smoking status) and pathologic (adenocarcinoma) criteria might identify a subgroup of patients with advanced/metastatic NSCLC who can benefit from front-line treatment with erlotinib when mutation testing is not feasible [62, 63].

Even though plenty clinical trials showed good response rates and PFS [64, 65] in NSCLC patients with EGFR mutations, acquired resistance in these patients responsive to EGFR-TKIs is a major clinical problem [66]. Phase III randomized controlled trials of NSCLC EGFR mutated patients receiving EGFR TKIs as front line treatment versus platinum doublets carboplatin and paclitaxel have shown a benefit in response and progression-free survival, but not in overall survival [56]. Thus, EGFR gene mutation currently cannot be considered a reliable biomarker for consistent response in NSCLC.

Since gefitinib or erlotinib can provide temporary success only, the need of novel treatments is crucial. To overcome secondary EGFR-TKI resistance, both preclinical and clinical evidence suggest that irreversible TKIs such as afatinib or PF00299804, or combined approaches using multiple kinase inhibition [67] and vertical inhibition combining small molecules and anti-EGFR antibodies such as cetuximab (chimeric human-mouse anti-EGFR) [68] [69] seem to be more promising for the near future.

More specifically, afatinib an irreversible HER2 kinase inhibitor BIBW 2992, has been evaluated in Phase I studies [70] [71]. The determination of the maximum-tolerated dose for Phase II (50 mg/day) has been accomplished [71] and is currently being used in phase II clinical trials [72] (LUX-Lung clinical trial program). In a recent study by Hirsh et al results from LUX-Lung 1 trial were evaluated concerning symptom and Quality of Life benefit of afatinib in advanced NSCLC patients previously treated with erlotinib or gefitinib. They reported that the addition of afatinib to best supportive care (BSC) significantly improved NSCLC-related symptoms (cough, dyspnea, and pain), fatigue, physical functioning, and 
Health-Related Quality of Life (HRQoL) and significantly delayed time to deterioration of cough [73]. Afatinib has shown activity in the treatment of patients with advanced lung adenocarcinoma with EGFR mutations, especially in patients with deletion 19 or L858R mutations [74]. In a phase $2 \mathrm{~b} / 3$ randomised trial (LUX-Lung 1), afatinib versus placebo for NSCLC patients was evaluated, suggesting that afatinib could be benefit for patients with advanced lung adenocarcinoma who have failed at least 12 weeks of previous EGFR TKI treatment [75]. After these studies of afatinib that have shown high RR and PFS in EGFR mutation-positive lung adenocarcinoma, recently the LUX-Lung 3 study reported that afatinib was associated with prolongation of PFS when compared with standard doublet chemotherapy (cisplatin plus pemetrexed) in patients with advanced lung adenocarcinoma and EGFR mutations [76].

Rossi et al in their review supported also the hypothesis that gefitinib, erlotinib and afatinib are ideal drugs for NSCLC patients carrying EGFR mutations [77].

In addition, according to several phase II and III clinical trials, chemoradiotherapy (CRT) has only extended survival to 18 to 20 months [78-83]. Other clinical trials have investigated the combination of gefitinib and erlotinib with radiation alone or chemoradiotherapy for stage III NSCLC reporting well tolerated and feasible results [84-86]. Results of a phase II study, (cancer and leukemia group B (CALEB) 30106) showed that survival of poor-risk patients with wild type or mutated EGFR receiving sequential CRT with gefitinib was promising where-as survival for good-risk patients receiving concurrent CRT plus gefitinib was disappointing even for tumors with activating EGFR mutations [85]. A prospective study showed that concur-rent EGFR-TKIs with individualized radiotherapy had a favorable safety profile and promising outcome [87]. An Asian study also reported that the combination of first-line TKI therapy with early multi-target radiotherapy were very effective in selected patients that respond to TKI, when the EGFR mutation status are not known before the treatment [88]. A more recently published study, compared the time-to-response between radiothera-py and EGFR-TKIs, concluding that EGFR-TKIs accomplished tumor shrinkage earlier than radiotherapy did in NSCLC patients with a sensitive EGFR mutation, suggesting that EGFR-TKIs might be useful for early symptom improvement in these patients [89].

Other new pharmaceutical agents that bind irreversibly to EGFR tyrosine kinase include neratinib (HKI-272) and dacomitinib (PF-00299804) which have been evaluated in phase II clinical trials [90] [91].
Sequist et al that studied neratinib to overcome T790M resistance mutation reported responses in G719X EGFR mutation, supporting the need of genetic information on trials of targeted agents [90]. According to Ramalingam et al, dacomitinib demonstrated significantly improved PFS versus erlotinib, with acceptable toxicity [91].

Moreover, cetuximab (marketed as Erbitux ${ }^{\circledR}$; Dako, Copenhagen, Denmark) is a $152 \mathrm{kDa}$ chimeric monoclonal antibody of the immunoglobulin G1 subclass produced in mammalian cell culture by mouse myeloma cells [92]. Cetuximab plus gemcitabine/ platinum [93] or plus cisplatin/vinorelbine [94] has been evaluated in randomized phase II clinical trials as first-line therapy with promising results in unselected NSCLC patients.

However in a multicenter, open-label, phase III study of 676 chemotherapy-naïve NSCLC patients, paclitaxel or docetaxel and carboplatin, with or without cetuximab were evaluated as first-line treatment, resulting in no notable differences between them [95]. Analysis of potential predictive markers of cetuximab benefit of this phase III trial reported that efficacy parameters did not appear to correlate with K-ras mutation status or any of the EGFR-related biomarkers evaluated [96]. In contrast, Hirsch et al in their study were the first to suggest that EGFR gene copy number detected by fluorescent in situ hybridization (FISH) is a predictive factor for selection of NSCLC patients for cetuximab plus chemotherapy [97].

In another multinational, multicentre, open-label, phase III trial, (FLEX study) chemotherapy-naive patients (>or=18 years) with advanced EGFR-expressing histologically or cytologically proven stage wet IIIB or stage IV NSCLC were randomly assigned in a 1:1 ratio to chemotherapy plus cetuximab or just chemotherapy [98]. The FLEX study reported that overall and median survival rates were also higher in the chemotherapy plus cetuximab group as compared to the chemotherapy alone group in patients with high EGFR expression [98].

Other studies have also favored cetuximab in NSCLC patients. In an open label phase II clinical trial in pretreated NSCLC patients, cetuximab was evaluated as monotherapy resulting in disease control rates and OS comparable to that of pemetrexed, docetaxel, and erlotinib in similar groups of patients [99]. Lin et al in a meta-analysis of four trials enrolling 2018 previously untreated NSCLC patients, showed that the addition of cetuximab to chemotherapy improved OS and overall response rate (ORR) [100]. Overall, as most studies have reported, cetuximab can offer a clinical benefit in NSCLC patients but warrants further investigation. 
Recently, acquired resistance to TKIs has been reported to include mechanisms such as secondary mutation of the EGFR gene, amplification of the MET gene, and overexpression of hepatocyte growth factor (HGF) [66].

Met is the tyrosine kinase (TK) receptor of the HGF and has been associated with a worse prognosis in NSCLC, activating the ERBB3/PI3K/AKT and GRB2-associated binding protein 1(GAB1) signaling in EGFR-mutant lung cancers [101]. According to Ma et al the Met/HGF pathway is functional and often mutated in SCLC and NSCLC (53).

MetMAb (Oartuzumab) is a monovalent monoclonal antibody (MoAb), a promising agent to overcome this resistance. A completed phase II study with results included the combination of MetMAb with erlotinib in patients with advanced and previously treated NSCLC patients improving PFS and OS in those patients whose tumors overexpressed Met by immunohistochemistry (IHC; 'Met high') [102]. After these encouraging results, a similar phase III clinical trial has been launched since 2011 to evaluate the efficacy and safety of MetMab and is still recruiting patients.

Other ongoing randomized, phase II, multicenter, double-blind, placebo-controlled studies are investigating MetMab in combination with paclitaxel plus cisplatin/carboplatin (NCT00854308) and in combination with bevacizumab plus platinum plus paclitaxel/pemetrexed plus platinum as first-line treatment (NCT01496742), both in untreated non-squamous NSCLC patients (http://www.clinical trials.gov/ct2 $/$ results?term=MetMAb+NSCLC\&Searc $\mathrm{h}=$ Search).

Tivantinib (ARQ 197), a selective, oral, non-ATP-competitive, small-molecule inhibitor of the MET receptor tyrosine kinase was evaluated in a phase 1 dose-escalation trial [103] or in combination with erlotinib [104] showing good tolerability and encouraging clinical activity. Recently, studies have been designed such as MARQUEE, a phase III trial to evaluate the combination of ARQ 197 plus erlotinib versus placebo plus erlotinib in treated nonsquamous, NSCLC previously patients [105] based on the available evidence that dual inhibition of MET and EGFR might overcome resistance to EGFR inhibitors.

Another emerging tool for the implementation of personalized medicine includes the K-ras gene mutation. The K-ras gene functions in the downstream domain of EGFR-induced cell signaling by encoding a 21-kDa G-protein with GTPase activity and has a mutation frequency of $3-35 \%$ in lung cancer [106, 107]. In particular, K-ras mutations have been found in approximately $17 \%$ of all NSCLC, and are seen in $27 \%-34 \%$ of adenocarcinomas and non-squamous tumors, but are rarely seen in squamous cell carcinomas $[108,109]$. These mutations are located at codons 12 and 13 and rarely at codons 59 and 61 [110]. Moreover, a meta-analysis of studies in advanced NSCLC provided empirical evidence that K-ras mutations are highly specific negative predictors of response (de-novo resistance) to single-agent EGFR TKIs [111].

Other groups reported that the clinical usefulness of K-ras mutation as a selection marker either for EGFR-TKIs or cetuximab sensitivity in NSCLC is limited [112] [113].

In a French prospective cohort (ERMETIC project--part 2) by Cadranel et al [114] in NSCLC patients treated by erlotinib, was reported that EGFR and K-ras status independently impact outcomes in advanced NSCLC patients treated with EGFR-TKI. However, EGFR status impacts both PFS and OS, whereas K-ras only impacts OS. These findings supported the nationwide use of EGFR status for patient selection before EGFR-TKI therapy. Although there are some studies in the literature investigating the EGFR and K-ras mutations in NSCLC tumor samples simultaneously [111], the role of K-ras mutations remains to be elucidated. Overall, all these data suggest the possible existence of two different molecular pathways one associated (K-ras mutation) and another not associated with smoking (EGFR mutation).

The PI3K/AKT/mTOR pathway is also being investigated via inhibited targeted agents in the setting of pathway-activating mutations and for their ability to restore sensitivity to upstream signaling targeted agents [115].

Drugs interfering with the mTOR pathway include rapamycin (sirolimus), and its derivatives cell cycle inhibitor (CCI)-779 (temsirolimus) and RAD001 (everolimus) [116] which have been investigated in phase I and II clinical trials. Although mTOR inhibitors such as everolimus in combination with EGFR inhibitors appear to be well tolerated, with some evidence suggesting antitumor activity [117], optimization of the therapeutic impact of mTOR inhibitors in NSCLC will be further defined when reliable predictive factors are identified. The most recent study conducted by Ramalingam et al [118] included a phase II trial of docetaxel in combination with everolimus for salvage therapy of NSCLC patients with relatively modest efficacy in this unselected population. Furthermore, since EGFR-TKIs therapy includes primary or acquired resistance, a preclinical study in NSCLC lines concluded that the use of everolimus might enhance the efficacy of gefitinib in EGFR-TKI-resistant patients [119]. Besides another study indicated that transient blockade of PI3K/Akt pathway might overcome EGFR TKIs re- 
sistance and restore sensitivity to agents well tolerated, thereby providing clinical benefit in NSCLC patients [120]. The PI3K/AKT/mTOR pathway includes $\mathrm{Akt}$, one of the most frequently activated protein kinases in human cancer [115].

Overall, mTOR pathway currently can only be considered for second or third-line treatment [118, 121]. More biomarkers and novel biological agents are required to be tested in clinical trials for mTOR pathway to play a crucial role in NSCLC therapy in the future [122].

The investigation for other genetic abnormalities has led to the identification of anaplastic lymphoma kinase (ALK) gene rearrangements which occurs independently of EGFR and KRAS gene mutations. This genetic change is consisted in a chromosome 2 inversion leading to a fusion with the echinoderm microtubule-associated protein like 4 (EML4) gene, which results in the abnormal expression and activation of this tyrosine kinase in the cytoplasm of cancer cells [123].

EML4-ALK (anaplastic lymphoma kinase) fusion which is a rare abnormality appeared in $4-5 \%$ of NSCLC patients [124] is most common in adenocarcinomas and never or light smokers $[125,126]$.

In pretreated NSCLC patients that carry the ALK-translocation, Met and ALK inhibitor crizotinib (PF- 02341066) appears to be a favorable treatment option, which significantly can improve activity, efficacy and symptoms control versus chemotherapy [127]. Crizotinib showed good tolerability with rapid, durable responses in the first-in-man phase I study for patients with EML4-ALK fusion [128]. In another phase 1-2 study crizotinib was well tolerated and highly active in patients with advanced ALK-rearranged NSCLC [129].

At present phase III clinical trials (NCT01639001) evaluate the efficacy and safety of crizotinib versus pemetrexed/cisplatin or pemetrexed/carboplatin in previously untreated East Asian patients with non-squamous carcinoma of the lung harboring a translocation or inversion event involving the ALK Gene Locus.

Based on these results and those from an ongoing phase II trial (NCT00932451), crizotinib has received accelerated approval in the USA [130]. However, the evaluation of crizotinib in combination with other therapeutic modalities including ionizing radiation remains to be investigated, since resistance to crizotinib might also be a fact [123]. Also, an interesting conclusion in vitro was reported recently in a study that crizotinib overcame hepatocyte growth factor-mediated resistance to gefitinib in EGFR-mutant non-small-cell lung cancer cells [131].

Another important signaling pathway in NSCLC includes type I insulin-like growth factor receptor (IGF-1R) [132] which is a heterotetrameric receptor (two extracellular $125-\mathrm{kDa}$ a chains and two transmembrane $95-\mathrm{kDa} \beta$ chains) that auto-phosphorylates after ligand binding and activates other downstream signaling pathways such as PI3K and MAPK [133]. IGF-1R-targeted agents include monoclonal antibodies such as cixutumumab (IMC-A12), figitumumab (CP-751,871), AMG-479, AVE1642, BIIB022, dalotuzumab (MK-0646), and robatumumab (Sch717454), the ligand neutralizing antibody Medi-573, and the small molecule inhibitors BMS-754807, linsitinib (OSI-906), XL228, and AXL1717.

Since IGF-1R and EGFR appear to be similar receptors in their signaling mechanisms, there is a possibility that IGF-1R signaling might be involved in tumor resistance to EGFR-TKIs as suggested in several studies in vitro [134] [135]. Based on this possibility, several trials have been designed such as the combinations of erlotinib with cixutumumab [136] or figitumumab combined with carboplatin and paclitaxel [137], all reported very limited results. Given the unsatisfactory results further development of this combination in unselected patients is not recommended. However, the identification of elevated baseline free IGF-1 levels in patients with longer PFS than in those with lower levels in several studies [134, 136-139] might represent a potential biomarker for optimal patient preselection for IGF-1R inhibitors in the future.

\section{Targeted agents versus docetaxel}

Plenty of studies revealed the superiority of gefitinib versus platinum-based and docetaxel chemotherapies. However, some of the following studies were conducted in unselected patients, thus precluding a true analysis of the real efficacy of targeted therapy in EGFR patients. Some study groups have compared gefitinib to docetaxel as second-line therapy in pre-treated patients with at least one prior chemotherapy regimen (platinum- or taxane-based) for advanced/metastatic NSCLC [140]. The majority of the studies concluded similar or superior efficacy for gefitinib compared with docetaxel, supporting gefitinib as an effective treatment in NSCLC [141-145]. (Table 2.) Herein, we summarize, the high lightened studies that have reported results concerning the comparison between EGFR TKIs and docetaxel. 
Table 2. Combination of targeted agents in NSCLC.

\begin{tabular}{|c|c|c|c|c|c|c|c|c|}
\hline First author/Study & $\begin{array}{l}\text { Primary End- } \\
\text { point/objective }\end{array}$ & Place & $\mathbf{n}$ & Targeted agents & $\begin{array}{l}\text { Inhibition } \\
\text { of molecu- } \\
\text { lar path- } \\
\text { ways }\end{array}$ & PHASE & STAGE/PATIENTS & Comments \\
\hline $\begin{array}{l}\text { Herbst et al } 2011 \\
(\text { BeTa) }\end{array}$ & OS & USA & 636 & $\begin{array}{l}\text { bevacizumab plus erlotinib vs } \\
\text { erlotinib alone }\end{array}$ & $\begin{array}{l}\text { EGFR + } \\
\text { VEGFR }\end{array}$ & III & $\begin{array}{l}\text { recurrent or refracto- } \\
\text { ry/pretreated } 1^{\text {st }} \text { line } \\
\text { treatment }\end{array}$ & $\begin{array}{l}\text { not improved } \\
\text { OS }\end{array}$ \\
\hline $\begin{array}{l}\text { Papadimitrakopoulou } \\
\text { et al } 2012\end{array}$ & $\begin{array}{l}\text { feasible dosages of } \\
\text { combination therapy }\end{array}$ & Greece & 94 & $\begin{array}{l}\text { erlotinib }+ \text { everolimus as } 2 \text { nd } \\
\text { and } 3 \text { rd line }\end{array}$ & $\begin{array}{l}\mathrm{EGFR}+ \\
\mathrm{mTOR}\end{array}$ & I & $\begin{array}{l}\text { refractory ad- } \\
\text { vanced/pretreated } \\
\text { platinum-taxanes based } \\
\text { CT }\end{array}$ & $\begin{array}{l}\text { acceptable } \\
\text { tolerability and } \\
\text { disease control }\end{array}$ \\
\hline Scagliotti et al 2012 & OS & Italy & 960 & Sunitinib Plus Erlotinib & $\begin{array}{l}\text { EGFR + } \\
\text { VEGFR }\end{array}$ & III & $\begin{array}{l}\text { Pretreated/ at least one } \\
\text { platinum-based regi- } \\
\text { men }\end{array}$ & $\begin{array}{l}\text { significantly } \\
\text { longer } \\
\text { PFS and greater } \\
\text { ORR }\end{array}$ \\
\hline Boutsikou et al 2013 & OS & Greece & 229 & erlotinib and/or bevacizumab & $\begin{array}{l}\text { EGFR + } \\
\text { VEGFR }\end{array}$ & III & $\begin{array}{l}\mathrm{IIIb} / \mathrm{IV} \text { non-squamous/ } \\
\text { pretreated docet- } \\
\text { axel-carboplatin }\end{array}$ & $\begin{array}{l}\text { promising but } \\
\text { not improved } \\
\text { OS }\end{array}$ \\
\hline Falchook et al 2013 & $\begin{array}{l}\text { Evaluation of this } \\
\text { combination treat- } \\
\text { ment for the first time }\end{array}$ & USA & 34 & $\begin{array}{l}\text { erlotinib, cetuximab, and } \\
\text { bevacizumab }\end{array}$ & $\begin{array}{l}\text { EGFR + } \\
\text { VEGFR }\end{array}$ & I & advanced/pretreated & $\begin{array}{l}\text { well-tolerated, } \\
\text { antitumor } \\
\text { activity }\end{array}$ \\
\hline
\end{tabular}

In the largest phase III INTEREST trial, 1.466 pretreated patients with advanced NSCLC were randomly assigned to receive gefitinib or docetaxel [146]. They suggested that gefitinib is a valid treatment for these pretreated patients. Two years later, other researchers from the same institute, prospectively analyzed available tumor biopsies of these NSCLC patients, to investigate the relationship between biomarkers and clinical outcomes [147]. They suggested that gefitinib can provide similar OS to docetaxel in patients across a broad range of clinical subgroups and that EGFR biomarkers such as mutation status may additionally identify which patients are likely to gain greatest PFS and ORR benefit from gefitinib.

Another international randomised multicentre, open-label, phase III study (TITAN-NCT00556322) which was conducted at 77 sites in 24 countries assessed the efficacy and safety of erlotinib versus chemotherapy in second-line treatment of NSCLC patients $(\mathrm{N}=2590)$. Although no significant differences in efficacy were noted between patients treated with erlotinib and those treated with docetaxel or pemetrexed, the toxicity profiles of erlotinib and chemotherapy differed. Therefore, they concluded that second-line treatment decisions should take into account patient preference and specific toxicity risk profiles [32].

A cost-effectiveness analysis was conducted which concluded that costs and effectiveness in patients who received second-line erlotinib compared with those who received docetaxel were equal [148]. They also suggested that the choice of whether to use erlotinib or docetaxel should be based on factors relating to patient preference. Besides, another study by Krawczyk et al $(\mathrm{N}=204)$ suggested that the qualification of docetaxel or erlotinib for second-line ther- apy should be based on clinical and molecular predictive factors [149].

\section{Gefitinib and Erlotinib}

Recently several studies have compared the efficacies of gefitinib and erlotinib as potent EGFR TKIs with antitumor activity in NSCLC patients [14]. In a randomized, single-center, non-comparative phase II trial, by Kimet al the efficacy and safety of gefitinib and erlotinib was evaluated as second-line therapy for advanced NSCLC $(\mathrm{N}=96)$ with promising results for both of them [150]. In a taiwanese retrospective multicenter study $(\mathrm{N}=1122)$ was reported that patients treated with erlotinib showed higher disease control rate, longer PFS, and OS compared with patients treated with gefitinib [151]. Shao et al compared the efficacies of gefitinib and erlotinib as third-line therapy for advanced non-small-cell lung cancer inTaiwan $(\mathrm{N}=984)$ resulting in similar efficacies [152].

Recently completed trials involved erlotinib as monotherapy (BR.21 study) after the failure of first-line or second-line chemotherapy [21] or in combination with standard chemotherapeutic regimens such as carboplatin and paclitaxel [153] (TRIBUTE trials) for the treatment of NSCLC. TRIBUTE results concluded that never smokers treated with erlotinib and chemotherapy seemed to experience an improvement in survival.

Conversely, erlotinib has exhibited overall survival benefits when used as monotherapy (BR.21 study) [21].

EGFR TKIs gefitinib and erlotinib have also been studied versus other inhibitors and other chemotherapeutics regimens. Natale et al [154] in a two-part phase II study, compared the efficacy and safety of 
vandetanib a once-daily oral inhibitor of VEGFR, with that of gefitinib, $(\mathrm{N}=168)$. The primary efficacy objective was achieved, with vandetanib demonstrating a significant prolongation of PFS versus gefitinib.

Furthermore, Hong et al [155] compared the efficacy and safety of pemetrexed, gefitinib, and erlotinib administration in previously treated patients with NSCLC. The superior PFS and OS of EGFR TKIs with more favorable baseline clinical characteristics than those of pemetrexed suggested the impact of baseline clinicopathological factors.

Moreover, some study groups investigated erlotinib as salvage treatment after failure of gefitinib with limited results, suggesting the need of the identification of molecular biomarkers in tumors to understand and overcome acquired resistance to gefitinib [156-159]. (Table 1)

In a systematic review of 28 trials with a total of 6171 NSCLC patients and 30 treatments arms, they found that there was a significant relationship between Response Rate (RR) and Median Survival Time (MST) in these clinical trials with EFGR-TKIs by using a linear progression model [160]. They suggested that RR could be an independent surrogate marker for MST in the current response criteria in the clinical trials of gefitinib and erlotinib. Overall, gefitinib and erlotinib appear to show a lot of similarities in NSCLC treatment and no superiority is obvious.

\section{EGFR TKIs and elderly patients}

Several efforts have been made towards the evaluation of the activity and toxicity profile of gefitinib in NSCLC patients aged 70 years or older. Since 2004, several studies reported that gefitinib is safe and well tolerated in elderly pretreated NSCLC patients [161] [162] [163].

Furthermore, in a phase II Simon et al reported that docetaxel $(75 \mathrm{mg} / \mathrm{m}$ (2) every 3 weeks) combined with gefitinib ( $250 \mathrm{mg}$ orally, daily) is active and well tolerated in elderly patients [164]. However, in studies of Stinchcombe et al in a phase I/II trial of weekly docetaxel and gefitinib in these patients with stage IIIB/IV NSCLC, unexpected toxicity was observed $[165,166]$.

A phase II, open-label, parallel-group study compared gefitinib with vinorelbine in chemotherapy-naïve elderly patients with advanced NSCLC was conducted by Crinò et al [167]. They reported no statistical difference between gefitinib and vinorelbine in efficacy in these patients, but there was better tolerability with gefitinib.

Finally studies to verify safety and efficacy of first-line treatment with gefitinib in elderly patients having advanced NSCLC with promising results were reported by Maemondo et al and Ebi et al [168, 169].
In addition, erlotinib was evaluated mostly in phase II clinical trials in vulnerable elderly NSCLC patients with feasible results [170] [166, 171-173]. In particular, the GFPC 0505 study a multicenter phase II randomized trial of gemcitabine followed by erlotinib at progression, versus the reverse sequence, in vulnerable elderly patients with advanced NSCLC selected with a comprehensive geriatric assessment (the GFPC 0505 study) was reported that both strategies were feasible but had modest efficacy [170]. Moreover, Wheatley-Price et al [174] analyzed the influence of age on outcomes in National Cancer Institute of Canada Clinical Trials Group Study BR.21. They reported that elderly patients treated with erlotinib gain similar survival and QoL benefits as younger patients but experience greater toxicity.

\section{Targeting vascular endothelial growth factor receptor (VEGFR)}

Vascular endothelial growth factor (VEGF) family of proteins includes VEGF-A, B, C, D, and E, and placental growth factor 1 and 2 [175]. VEGF an endothelial cell-specific mitogen is the major regulator of angiogenesis in normal and malignant tissue [176, 177]. The VEGF pathway includes; i) monoclonal antibodies against VEGF such as bevacizumab which has been approved for the treatment of metastatic nonsquamous NSCLC in combination with carboplatin and paclitaxel and has shown increased survival [178], ii) VEGF receptors such as aflibercept and pazopanib and iii) small molecule TKIs such as sunitinib and sorafenib that target the TK domain of VEGF receptor [179]. (Table 1.)

Bevacizumab is a recombinant humanized monoclonal antibody (MoAb) that binds to and neutralizes human vascular endothelial growth factor (VEGF) [180]. The first trial to establish the combination of bevacizumab and cytotoxic chemotherapy as a new standard of care for eligible NSCLC patients was ECOG [22] resulting in significant survival benefit with the risk of increased treatment-related deaths. Another study (JO19907) demonstrated that the addition of bevacizumab to first-line carboplatin-paclitaxel significantly improved PFS in Japa-nese patients with advanced non-squamous NSCLC [178]. A Phase III trial (AVAil) of cisplatin plus gemcitabine with either placebo or bevacizumab as first-line therapy for nonsquamous NSCLC significantly improved PFS and ORR [181].

Recently, an open randomized clinical trial (WJOG 5910L) has been designed to evaluate whether the addition of bevacizumab to docetaxel alone (the standard second-line treatment for NSCLC) might improve PFS when administered as second-line treatment in NSCLC patients who have progressed 
after first-line treatment with bevacizumab plus a platinum based doublet [182].

Approvals for bevacizumab, were based upon the results of the two large phase III studies the North American Eastern Cooperative Oncology Group (ECOG) 4599 [22] and the European AVAiL [21] concerning the improvement in RR and PFS. Overall, bevacizumab plus platinum-based chemotherapy offers clinical benefit for bevacizumab-eligible patients with advanced NSCLC. As a result to the exciting role of bevacizumab in NSCLC, other anti-angiogenic agents, including small molecule TKIs targeting the vascular endothelial growth factor receptor (VEGFR) have developed and are currently being explored.

The latest goal of the researchers is the evaluation of antiangiogenics in combination with radiotherapy. Data do not support the combination of bevacizumab and radiation [183]. Aflibercept a recombinant human fusion protein targeting the VEGF is either well tolerated in phase II trials with platinum- and erlotinib-resistant lung adenocarcinoma [184] or disappointing results in phase III clinical trials [185] in nonsquamous NSCLC patients.

In a phase III trial that investigated OS for sunitinib, a VEGFR TKI plus erlotinib versus placebo plus erlotinib in patients with refractory NSCLC, concluded that the combination of sunitinib plus erlotinib was associated with a statistically significantly longer PFS and greater ORR [186]. Another VEGFR TKI, sorafenib inhibits the Ras/Raf pathway, which is overactive in cancer patients with a K-ras mutation, showed relevant clinical activity in a phase II study [187]. However, a Phase III, randomized, double-blind, placebo-controlled trial of gemcitabine/cisplatin alone or with sorafenib for the first-line treatment of advanced, nonsquamous NSCLC did not meet its primary end point of improved OS [188].

Furthermore, Motesanib is a selective oral inhibitor of VEGF receptors-1, 2, and 3, platelet-derived growth factor receptor (PDGFR) that showed encouraging results in a phase II trial [189] in combination with carboplatin/paclitaxel as frontline therapy in NSCLC which led to the development of the MONET1 study. However, this phase III trial failed to achieve its primary endpoint of OS when adding a VEGFR TKI to first-line chemotherapy [190].

Another VEGR inhibitor is pazopanib (GW786034; GlaxoSmithKline, Philadelphia) which has been evaluated as monotherapy in phase II trial with favorable results. Several clinical trials that are currently ongoing or recruiting or even completed, include pazopanib in combination with erlotinib (NCT01027598) or with vinorelbine (NCT01060514), in combination (NCT00871403) and in comparison to pemetrexed (NCT01313663) and data are keenly awaited. http:/ / www.clinicaltrials.gov/ct2/results?t erm=Pazopanib+NSCLC\&Search=Search

Additionally, Vandetanib (AstraZeneca, Macclesfield, UK, ZACTIMA ${ }^{\mathrm{TM}}$ ZD6474) is a once-daily oral anticancer drug, a dual inhibitor of vascular endothelial growth factor receptor (VEGFR) and epidermal growth factor receptor(EGFR) signaling [191, 192]. Phase I [193] and Phase II studies have favored vandetanib in pre-treated NSCLC patients plus docetaxel (ZODIAC) [191], versus gefitinib[154], as monotherapy [194] or as first line treatment alone or with paclitaxel and carboplatin [195]. Recently, after these encouranging data, phase III have been initiated including vandetanib plus pemetrexed for the second-line treatment [196] resulting in acceptable safety profile. However, in other phase III trials vandetanib was evaluated versus erlotinib [197] or versus placebo (ZEPHYR) [198] in pretreated patients with disappointing results.

Overall, except for bevacizumab, the part of other agents targeting VEGFR that are under clinical development is still limited today since several issues such as predictive biomarkers of response to antiangiogenic therapy and mechanisms of resistance to these agents remain to be elucidated.

\section{Maintenance treatment (MT) for NSCLC}

The current practice of first-line therapy for advanced NSCLC is four to six cycles of platinum-based combination chemotherapy followed by treatment break in non-progressive status [199]. Moreover, only approximately $60 \%$ of patients would experience disease control at 8 weeks [200] and the median OS observed in recent trials of platinum-based double-agent chemotherapy has been 10 to 13 months $[201,202]$. Therefore, researchers have tried to prolong disease control obtained with first-line chemotherapy by additional therapy, in an attempt to improve OS, with preserved QoL. This additional chemotherapy is called maintenance treatment which can be consisted of a drug included in the induction regimen (so-called "continuation" MT) or early introduction of another non-cross-resistant agent ("switch" or consolidation MT) [203]. We performed an electronic clinical trial search through PubMed data base including the following studies that state clearly in their title the application of maintenance treatment in NSCLC patients. (Table 3.) Although until a few years ago, no MT studies have shown an OS benefit, recently several studies have revealed the clinical benefit of maintenance therapy $[203,204]$. 
Table 3. Maintenance treatment in NSCLC, Disease Control Rate (DCR), Progression Free Survival PFS)

\begin{tabular}{|c|c|c|c|c|c|c|c|}
\hline First author/Study & $\mathbf{n}$ & Place & $\begin{array}{l}\text { Primary } \\
\text { Endpoint }\end{array}$ & Phase & STAGE & $\begin{array}{l}\text { MAINTENANCE } \\
\text { TREATMENT }\end{array}$ & Patients \\
\hline Pallis et al 2007 & 41 & Greece & DCR & II & IIIB/IV & $\begin{array}{l}\text { gefitinib as salvage } \\
\text { treatment }\end{array}$ & Pretreated platinum- or taxane-based \\
\hline $\begin{array}{l}\text { Kelly et al } 2008 \\
\text { (SWOG S0023) }\end{array}$ & 243 & USA & - & III & III & gefitinib or placebo & $\begin{array}{l}\text { Pretreated concurrent chemoradio- } \\
\text { therapy and docetaxel }\end{array}$ \\
\hline Patel et al 2009 & 50 & USA & PFS & II & $\begin{array}{l}\text { IIIB/IV } \\
\text { nonsquamous }\end{array}$ & $\begin{array}{l}\text { pemetrexed and } \\
\text { bevacizumab }\end{array}$ & $\begin{array}{l}\text { Untreated } 1^{\text {st }} \text { line pemetrexed, car- } \\
\text { boplatin, and bevacizumab }\end{array}$ \\
\hline $\begin{array}{l}\text { Zhang et al } 2012 \\
\text { (INFORM; C-TONG 0804) }\end{array}$ & 296 & China & PFS & III & IIIb or IV & Gefitinib versus placebo & $\begin{array}{l}\text { Pretreated 1st-line platinum-based } \\
\text { doublet }\end{array}$ \\
\hline $\begin{array}{l}\text { Cappuzzo et al } 2010 \\
\text { (SATURN; BO18192) }\end{array}$ & 884 & Italy & PFS & III & advanced & erlotinib & $\begin{array}{l}\text { Pretreated } 1^{\text {st }} \text { line/four cycles of } \\
\text { platinum-based chemotherapy }\end{array}$ \\
\hline
\end{tabular}

Agents that have recently been licensed as maintenance therapy for advanced NSCLC by the US Food and Drug Administration include erlotinib and pemetrexed [205]. However this new setting still remains controversial as there is no certainty that maintenance treatment is superior to second or third line therapy [206].

The first agent to be integrated into the treatment regimen was gefitinib, as a MT. Kelly et al in a phase III trial of maintenance gefitinib or placebo after concurrent chemoradiotherapy and docetaxel consolidation in inoperable stage III NSCLC (SWOG S0023, $\mathrm{N}=243$ ) reported that gefitinib did not improve survival [207]. However, the latest study included a multicentre, double-blind randomised phase 3 trial (INFORM; C-TONG 0804, N=296) reported by Zhang et al [208]. They concluded that MT with gefitinib significantly prolonged PFS when compared with placebo in patients from East Asia with advanced NSCLC who achieved disease control after first-line chemotherapy.

Cappuzzo et al designed a phase III, placebo-controlled Sequential Tarceva in Unresectable NSCLC (SATURN; BO18192) study to assess the use of erlotinib as MT in patients with non-progressive disease following first-line platinum-doublet chemotherapy [209]. They reported that MT with erlotinib is well tolerated and significantly prolongs PFS compared with placebo and it could be considered in NSCLC patients who do not progress after four cycles of chemotherapy.

Furthermore, recently, Zhang et al [204] evaluated the efficacy and safety of erlotinib as MT in patients with unresectable NSCLC by evidence-based methodology from six eligible studies including 4372 patients. They reported that erlotinib produced significant clinical benefits with acceptable toxicity as a maintenance strategy in these patients, particularly when sequentially administered with chemotherapy but further suggested the comparison of the efficacy of erlotinib used as MT with second-line treatment.
Finally, a phase II study of bevacizumab plus pemetrexed and carboplatin followed by maintenance bevacizumab in patients with advanced, nonsquamous NSCLC was well tolerated and displayed remarkable activity in these patients [26]. Another phase II study of pemetrexed and carboplatin plus bevacizumab with maintenance pemetrexed and bevacizumab as first-line therapy concerning the same group of patients resulted in acceptable toxicity and relatively long survival [210].

After the 6 cycles of platinum chemotherapy, the patient may achieve no response and remain symptomatic or achieve response and become asymptomatic. In the first case, the big question concerns whether the subsequent therapy is "maintenance" or "early second-line therapy", and in the second case it concerns whether "maintenance therapy" is always better than "watch and wait". Overall, as the era of personalized therapy is emerging these decisions should be made on the underlying molecular profile of the individual patient. It is evident that combined treatments or not followed by MT of biological agents justify further investigation in NSCLC patients.

\section{Future perspectives}

All targeted agents mentioned in this review are directed toward key components in several signaling pathways. It is a fact that here is an increasing interest in using combinations of targeted agents to inhibit more than one pathway; for example, inhibition of VEGFR + EGFR [211]. Indeed, when dual inhibition was compared with VEGF or EGFR blockade alone, resulted in the reduction of tumor endothelial proliferation [212].

A phase I clinical trial included dual EGFR inhibition in combination with anti-VEGF treatment in NSCLC patients [213]. They concluded that the combination of erlotinib, cetuximab, and bevacizumab was well-tolerated and demonstrated antitumor activity in heavily pretreated NSCLC patients. Similarly, 
in another phase I study, it was demonstrated that combination therapy with ertotinib plus cetuximab was well tolerated [214].

Additionally, Boutsikou et al in a four-arm Phase III trial in patients with NSCLC reported the administration of bevacizumab and erlotinib in combination with first-line chemotherapy, followed by bevacizumab and erlotinib monotherapy as maintenance [215]. They showed promising results, with reduced toxicity as compared with chemotherapy alone, but there was no longer OS. Moreover, in a double-blind, placebo-controlled, randomised phase III trial (BeTa), addition of bevacizumab to erlotinib did not improve survival in patients with recurrent or refractory NSCLC [216].

Recently, Biomarker-integrated Approaches of Targeted Therapy for Lung Cancer Elimination (BATTLE) trial included the first completed prospective, biopsy-mandated, biomarker-based, adaptively randomized study in 255 pretreated lung cancer patients receiving erlotinib, vandetanib, erlotinib plus bexarotene, or sorafenib [217]. The targeted treatment in this trial was based on relevant molecular biomarkers analyzed in fresh core needle biopsy specimens. They reported an impressive benefit from sorafenib among mutant-Kras patients.

It is evident that in the near future, researchers will investigate the majority of the agents in combination with other therapies, either conventional chemotherapy or targeted therapy and even produce multiple pathway inhibitors such as XL 184 (Cabozantinib). XL 184 is a multiple TKIs agent for MET and VEGFR2 which is currently being investigated in several clinical trials either alone or in combination with other agents such as erlotinib (http://www.clinicaltrials.gov/ct2/results?term $=$ XL $+184+$ NSCLC\&Search=Search).

Apart from identifying the most appropriate combinations in selected NSCLC patient subgroups, the definition of the optimal treatment doses is also crucial for the achievement of the best therapeutic index and perhaps not the performance of large trials in unselected patients. Besides it is also important even in negative trials to identify biomarkers of response although to avoid negative results, researchers need to produce more preclinical and early clinical data before large clinical trials are initiated.

Available targeted therapy should be given to patients presenting the target. To date, EGFR TKIs, bevacizumab and ALK inhibitors include the most successful targeted agents in NSCLC. Besides, a few biological agents have shown better response in certain histologic subtypes of NSCLC leading to the involvement of histology to guide therapy.

At this point, several novel therapeutic targets are currently being investigated in laboratories and in clinical trials. Furthermore, in order to accelerate the identification of individualized targets, the accomplishment of cheap next-generation sequencing technologies for adequate parts of the genome is at large.

In conclusion, a step towards the realization of personalized therapy has been accomplished in NSCLC, concerning the identification of molecular biomarkers. Thus, the therapeutic goal concerns as much possible molecular information for every patient. However, the physician should primarily take into account patient's profile and individual characteristics and of course patient's response to therapy given the multiple subsets of NSCLC each with its own molecular abnormalities.

\section{Competing Interests}

The authors have declared that no competing interest exists.

\section{References}

1. Fuster LM, Sandler AB. Select clinical trials of erlotinib (OSI-774) in non-small-cell lung cancer with emphasis on phase III outcomes. Clin Lung Cancer. 2004; 6 Suppl 1: S24-9.

2. Vijayalakshmi R, Krishnamurthy A. Targetable "driver" mutations in non small cell lung cancer. Indian J Surg Oncol. 2011; 2: 178-88. doi:10.1007/s13193-011-0108-0.

3. Alberg AJ, Brock MV, Samet JM. Epidemiology of lung cancer: looking to the future. J Clin Oncol. 2005; 23: 3175-85. doi:10.1200/JCO.2005.10.462.

4. Vineis P, Airoldi L, Veglia F, Olgiati L, Pastorelli R, Autrup H, et al. Environmental tobacco smoke and risk of respiratory cancer and chronic obstructive pulmonary disease in former smokers and never smokers in the EPIC prospective study. BMJ. 2005; 330: 277. doi:10.1136/bmj.38327.648472.82.

5. Tardon A, Lee WJ, Delgado-Rodriguez M, Dosemeci M, Albanes D, Hoover R, et al. Leisure-time physical activity and lung cancer: a meta-analysis. Cancer Causes Control. 2005; 16: 389-97. doi:10.1007/s10552-004-5026-9.

6. Lee IM. Physical activity and cancer prevention--data from epidemiologic studies. Med Sci Sports Exerc. 2003; 35: 1823-7. doi:10.1249/01.MSS.0000093620.27893.23.

7. Boffetta P. Epidemiology of environmental and occupational cancer. Oncogene. 2004; 23: 6392-403. doi:10.1038/sj.onc.1207715.

8. Arriagada R, Bergman B, Dunant A, Le Chevalier T, Pignon JP, Vansteenkiste J. Cisplatin-based adjuvant chemotherapy in patients with completely resected non-small-cell lung cancer. $\mathrm{N}$ Engl J Med. 2004; 350: 351-60. doi:10.1056/NEJMoa031644.

9. Winton T, Livingston R, Johnson D, Rigas J, Johnston M, Butts C, et al. Vinorelbine plus cisplatin vs. observation in resected non-small-cell lung cancer. N Engl J Med. 2005; 352: 2589-97. doi:10.1056/NEJMoa043623.

10. Dillman RO, Seagren SL, Propert KJ, Guerra J, Eaton WL, Perry MC, et al. A randomized trial of induction chemotherapy plus high-dose radiation versus radiation alone in stage III non-small-cell lung cancer. N Engl J Med. 1990; 323: 940-5. doi:10.1056/NEJM199010043231403.

11. Matsuda A, Yamaoka K, Tango T. Quality of life in advanced non-small cell lung cancer patients receiving palliative chemotherapy: A meta-analysis of randomized controlled trials. Exp Ther Med. 2012; 3: 134-40. doi:10.3892/etm.2011.368.

12. Chen AB, Cronin A, Weeks JC, Chrischilles EA, Malin J, Hayman JA, et al. Palliative Radiation Therapy Practice in Patients With Metastatic Non-Small-Cell Lung Cancer: A Cancer Care Outcomes Research and Surveillance Consortium (CanCORS) Study. J Clin Oncol. 2013; 31: 558-64. doi:10.1200/JCO.2012.43.7954.

13. Stinchcombe TE, Morris DE, Lee CB, Moore DT, Hayes DN, Halle JS, et al. Induction chemotherapy with carboplatin, irinotecan, and paclitaxel followed by high dose three-dimension conformal thoracic radiotherapy (74 Gy) with concurrent carboplatin, paclitaxel, and gefitinib in unresectable stage IIIA and stage IIIB non-small cell lung cancer. J Thorac Oncol. 2008; 3: 250-7. doi:10.1097/JTO.0b013e3181653cf4.

14. Yoshida T, Yamada K, Azuma K, Kawahara A, Abe H, Hattori S, et al. Comparison of adverse events and efficacy between gefitinib and erlotinib in patients with non-small-cell lung cancer: a retrospective analysis. Med Oncol. 2013; 30: 349. doi:10.1007/s12032-012-0349-y. 
15. Tran B, Dancey JE, Kamel-Reid S, McPherson JD, Bedard PL, Brown AM, et al. Cancer genomics: technology, discovery, and translation. J Clin Oncol. 2012; 30: 647-60. doi:10.1200/JCO.2011.39.2316.

16. Koh PK, Faivre-Finn C, Blackhall FH, De Ruysscher D. Targeted agents in non-small cell lung cancer (NSCLC): clinical developments and rationale for the combination with thoracic radiotherapy. Cancer Treat Rev. 2012; 38: 626-40. doi:10.1016/j.ctrv.2011.11.003.

17. Langer CJ, Mok T, Postmus PE. Targeted agents in the third-/fourth-line treatment of patients with advanced (stage III/IV) non-small cell lung cancer (NSCLC). Cancer Treat Rev. 2013; 39: 252-60. doi:10.1016/j.ctrv.2012.05.003.

18. Azzoli CG, Temin S, Giaccone G. 2011 Focused Update of 2009 American Society of Clinical Oncology Clinical Practice Guideline Update on Chemotherapy for Stage IV Non-Small-Cell Lung Cancer. J Oncol Pract. 2012; 8: 63-6. doi:10.1200/JOP.2011.000374.

19. Domvri K, Darwiche K., Zarogoulidis P., Zarogoulidis K. Following the crumbs: from tissue samples, to pharmacogenomics, to NSCLC therapy. Transl Lung Cancer Res. 2012. doi: 10.3978/j.issn.2218-6751.2012.12.06.

20. Lesko LJ, Atkinson AJ, Jr. Use of biomarkers and surrogate endpoints in drug development and regulatory decision making: criteria, validation, strategies. Annu Rev Pharmacol Toxicol. 2001; 41: 347-66. doi:10.1146/annurev.pharmtox.41.1.347.

21. Shepherd FA, Rodrigues Pereira J, Ciuleanu T, Tan EH, Hirsh V, Thongprasert $\mathrm{S}$, et al. Erlotinib in previously treated non-small-cell lung cancer. N Engl J Med. 2005; 353: 123-32. doi:10.1056/NEJMoa050753.

22. Sandler A, Gray R, Perry MC, Brahmer J, Schiller JH, Dowlati A, et al. Paclitaxel-carboplatin alone or with bevacizumab for non-small-cell lung cancer. N Engl J Med. 2006; 355: 2542-50. doi:10.1056/NEJMoa061884.

23. Cardarella S, Ortiz TM, Joshi VA, Butaney M, Jackman DM, Kwiatkowski DJ, et al. The introduction of systematic genomic testing for patients with non-small-cell lung cancer. J Thorac Oncol. 2012; 7: 1767-74. doi:10.1097/JTO.0b013e3182745bcb.

24. Zhan P, Qian Q, Yu LK. Prognostic value of COX-2 expression in patients with non-small cell lung cancer: a systematic review and meta-analysis. J Thorac Dis. 2013; 5: 40-7. doi:10.3978/j.issn.2072-1439.2013.01.02.

25. Ko E, Lee BB, Kim Y, Lee EJ, Cho EY, Han J, et al. Association of RASSF1A and p63 with Poor Recurrence-Free Survival in Node-Negative Stage I-II Non-Small Cell Lung Cancer. Clin Cancer Res. 2013; 19: 1204-12. doi:10.1158/1078-0432.CCR-12-2848.

26. Stevenson JP, Langer CJ, Somer RA, Evans TL, Rajagopalan K, Krieger K, et al. Phase 2 trial of maintenance bevacizumab alone after bevacizumab plus pemetrexed and carboplatin in advanced, nonsquamous nonsmall cell lung cancer. Cancer. 2012; 118: 5580-7. doi:10.1002/cncr.27576.

27. Hallqvist A, Bergman B, Nyman J. Health related quality of life in locally advanced NSCLC treated with high dose radiotherapy and concurrent chemotherapy or cetuximab--pooled results from two prospective clinical trials. Radiother Oncol. 2012; 104: 39-44. doi:10.1016/j.radonc.2012.05.006.

28. Spira A, Ettinger DS. Multidisciplinary management of lung cancer. N Engl J Med. 2004; 350: 379-92. doi:10.1056/NEJMra035536.

29. Shaw RJ, Cantley LC. Ras, PI(3)K and mTOR signalling controls tumour cell growth. Nature. 2006; 441: 424-30. doi:10.1038/nature04869.

30. Ohsaki Y, Tanno S, Fujita Y, Toyoshima E, Fujiuchi S, Nishigaki Y, et al. Epidermal growth factor receptor expression correlates with poor prognosis in non-small cell lung cancer patients with p53 overexpression. Oncol Rep. 2000; 7: 603-7.

31. Janku F, Garrido-Laguna I, Petruzelka LB, Stewart DJ, Kurzrock R. Novel therapeutic targets in non-small cell lung cancer. J Thorac Oncol. 2011; 6: 1601-12. doi:10.1097/JTO.0b013e31822944b3.

32. Ciuleanu T, Stelmakh L, Cicenas S, Miliauskas S, Grigorescu AC, Hillenbach $\mathrm{C}$, et al. Efficacy and safety of erlotinib versus chemotherapy in second-line treatment of patients with advanced, non-small-cell lung cancer with poor prognosis (TITAN): a randomised multicentre, open-label, phase 3 study. Lancet Oncol. 2012; 13: 300-8, doi:10.1016/S1470-2045(11)70385-0.

33. Kris MG, Natale RB, Herbst RS, Lynch TJ, Jr., Prager D, Belani CP, et al. Efficacy of gefitinib, an inhibitor of the epidermal growth factor receptor tyrosine kinase, in symptomatic patients with non-small cell lung cancer: a randomized trial. JAMA. 2003; 290: 2149-58. doi:10.1001/jama.290.16.2149.

34. Simon GR, Ruckdeschel JC, Williams C, Cantor A, Chiappori A, Rocha Lima CM, et al. Gefitinib (ZD1839) in previously treated advanced non-small-cell lung cancer: experience from a single institution. Cancer Control. 2003; 10: 388-95.

35. Fukuoka M, Yano S, Giaccone G, Tamura T, Nakagawa K, Douillard JY, et al. Multi-institutional randomized phase II trial of gefitinib for previously treated patients with advanced non-small-cell lung cancer (The IDEAL 1 Trial) [corrected]. J Clin Oncol. 2003; 21: 2237-46. doi:10.1200/JCO.2003.10.038.

36. Gaafar RM, Surmont VF, Scagliotti GV, Van Klaveren RJ, Papamichael D, Welch JJ, et al. A double-blind, randomised, placebo-controlled phase III intergroup study of gefitinib in patients with advanced NSCLC, non-progressing after first line platinum-based chemotherapy (EORTC 08021/ILCP 01/03). Eur J Cancer. 2011; 47: 2331-40. doi:10.1016/j.ejca.2011.06.045.

37. Lin WC, Chiu CH, Liou JL, Chen YM, Perng RP, Tsai CM. Gefitinib as front-line treatment in Chinese patients with advanced non-small-cell lung cancer. Lung Cancer. 2006; 54: 193-9. doi:10.1016/j.lungcan.2006.07.013.
38. Reck M, Buchholz E, Romer KS, Krutzfeldt K, Gatzemeier U, Manegold C. Gefitinib monotherapy in chemotherapy-naive patients with inoperable stage III/IV non-small-cell lung cancer. Clin Lung Cancer. 2006; 7: 406-11.

39. Suzuki R, Hasegawa Y, Baba K, Saka H, Saito H, Taniguchi H, et al. A phase II study of single-agent gefitinib as first-line therapy in patients with stage IV non-small-cell lung cancer. $\mathrm{Br} \mathrm{J}$ Cancer. 2006; 94: 1599-603. doi:10.1038/sj.bjc.6603159.

40. Wang MZ, Li LY, Wang SL, Zhang XT, Zhong W, Zhang L. Efficacy and safety of gefitinib as monotherapy for Chinese patients with advanced non-small cell lung cancer. Chin Med J (Engl). 2006; 119: 63-8.

41. Govindan R, Natale R, Wade J, Herbst R, Krebs A, Reiling R, et al. Efficacy and safety of gefitinib in chemonaive patients with advanced non-small cell lung cancer treated in an Expanded Access Program. Lung Cancer. 2006; 53: 331-7. doi:10.1016/j.lungcan.2006.04.013.

42. Ando M, Okamoto I, Yamamoto N, Takeda K, Tamura K, Seto T, et al. Predictive factors for interstitial lung disease, antitumor response, and survival in non-small-cell lung cancer patients treated with gefitinib. J Clin Oncol. 2006; 24: 2549-56. doi:10.1200/JCO.2005.04.9866.

43. Niho S, Kubota K, Goto K, Yoh K, Ohmatsu H, Kakinuma R, et al. First-line single agent treatment with gefitinib in patients with advanced non-small-cell lung cancer: a phase II study. J Clin Oncol. 2006; 24: 64-9. doi:10.1200/JCO.2005.02.5825.

44. Sanford M, Scott LJ. Gefitinib: a review of its use in the treatment of locally advanced/metastatic non-small cell lung cancer. Drugs. 2009; 69: 2303-28. doi:10.2165/10489100-000000000-00000.

45. Thatcher N, Chang A, Parikh P, Rodrigues Pereira J, Ciuleanu T, von Pawel J, et al. Gefitinib plus best supportive care in previously treated patients with refractory advanced non-small-cell lung cancer: results from a randomised, placebo-controlled, multicentre study (Iressa Survival Evaluation in Lung Cancer). Lancet. 2005; 366: 1527-37. doi:10.1016/S0140-6736(05)67625-8.

46. Giaccone G, Herbst RS, Manegold C, Scagliotti G, Rosell R, Miller V, et al. Gefitinib in combination with gemcitabine and cisplatin in advanced non-small-cell lung cancer: a phase III trial--INTACT 1. J Clin Oncol. 2004; 22: 777-84. doi:10.1200/JCO.2004.08.001.

47. Herbst RS, Giaccone G, Schiller JH, Natale RB, Miller V, Manegold C, et al. Gefitinib in combination with paclitaxel and carboplatin in advanced non-small-cell lung cancer: a phase III trial--INTACT 2. J Clin Oncol. 2004; 22: 785-94. doi:10.1200/JCO.2004.07.215

48. Lynch TJ, Bell DW, Sordella R, Gurubhagavatula S, Okimoto RA, Brannigan $\mathrm{BW}$, et al. Activating mutations in the epidermal growth factor receptor underlying responsiveness of non-small-cell lung cancer to gefitinib. N Engl J Med. 2004; 350: 2129-39. doi:10.1056/NEJMoa040938.

49. Sugio K, Uramoto H, Onitsuka T, Mizukami M, Ichiki Y, Sugaya M, et al. Prospective phase II study of gefitinib in non-small cell lung cancer with epidermal growth factor receptor gene mutations. Lung Cancer. 2009; 64: 314-8. doi:10.1016/j.lungcan.2008.09.010.

50. Yang CH, Yu CJ, Shih JY, Chang YC, Hu FC, Tsai MC, et al. Specific EGFR mutations predict treatment outcome of stage IIIB/IV patients with chemotherapy-naive non-small-cell lung cancer receiving first-line gefitinib monotherapy. J Clin Oncol. 2008; 26: 2745-53. doi:10.1200/JCO.2007.15.6695.

51. Mitsudomi T, Morita S, Yatabe Y, Negoro S, Okamoto I, Tsurutani J, et al. Gefitinib versus cisplatin plus docetaxel in patients with non-small-cell lung cancer harbouring mutations of the epidermal growth factor receptor (WJTOG3405): an open label, randomised phase 3 trial. Lancet Oncol. 2010; 11: 121-8. doi:10.1016/S1470-2045(09)70364-X.

52. Fukuoka $\mathrm{M}, \mathrm{Wu} \mathrm{YL}$, Thongprasert $\mathrm{S}$, Sunpaweravong $\mathrm{P}$, Leong SS, Sriuranpong $\mathrm{V}$, et al. Biomarker analyses and final overall survival results from a phase III, randomized, open-label, first-line study of gefitinib versus carboplatin/paclitaxel in clinically selected patients with advanced non-small-cell lung cancer in Asia (IPASS). J Clin Oncol. 2011; 29: 2866-74. doi:10.1200/JCO.2010.33.4235.

53. Paez JG, Janne PA, Lee JC, Tracy S, Greulich $\mathrm{H}$, Gabriel $\mathrm{S}$, et al. EGFR mutations in lung cancer: correlation with clinical response to gefitinib therapy. Science. 2004; 304: 1497-500. doi:10.1126/science.1099314.

54. Takano $\mathrm{T}$, Ohe $\mathrm{Y}$, Sakamoto $\mathrm{H}$, Tsuta $\mathrm{K}$, Matsuno $\mathrm{Y}$, Tateishi U, et al. Epidermal growth factor receptor gene mutations and increased copy numbers predict gefitinib sensitivity in patients with recurrent non-small-cell lung cancer. J Clin Oncol. 2005; 23: 6829-37. doi:10.1200/JCO.2005.01.0793.

55. Sequist LV. First-generation epidermal growth factor receptor tyrosine kinase inhibitors in EGFR mutation: positive non-small cell lung cancer patients. J Thorac Oncol. 2008; 3: S143-5. doi:10.1097/JTO.0b013e318174e981.

56. Mok TS, Wu YL, Thongprasert S, Yang CH, Chu DT, Saijo N, et al. Gefitinib or carboplatin-paclitaxel in pulmonary adenocarcinoma. N Engl J Med. 2009; 361: 947-57. doi:10.1056/NEJMoa0810699.

57. Maemondo M, Inoue A, Kobayashi K, Sugawara S, Oizumi S, Isobe H, et al. Gefitinib or chemotherapy for non-small-cell lung cancer with mutated EGFR. N Engl J Med. 2010; 362: 2380-8. doi:10.1056/NEJMoa0909530.

58. Thongprasert S, Duffield E, Saijo N, Wu YL, Yang JC, Chu DT, et al. Health-related quality-of-life in a randomized phase III first-line study of gefitinib versus carboplatin/paclitaxel in clinically selected patients from Asia with advanced NSCLC (IPASS). J Thorac Oncol. 2011; 6: 1872-80. doi:10.1097/JTO.0b013e31822adaf7.

59. Chen G, Feng J, Zhou C, Wu YL, Liu XQ, Wang C, et al. Quality of life (QoL) analyses from OPTIMAL (CTONG-0802), a phase III, randomised, open-label study of first-line erlotinib versus chemotherapy in patients with advanced 
EGFR mutation-positive non-small-cell lung cancer (NSCLC). Ann Oncol. 2013. doi:10.1093/annonc/mdt012.

60. Zhou C, Wu YL, Chen G, Feng J, Liu XQ, Wang C, et al. Erlotinib versus chemotherapy as first-line treatment for patients with advanced EGFR mutation-positive non-small-cell lung cancer (OPTIMAL, CTONG-0802): a multicentre, open-label, randomised, phase 3 study. Lancet Oncol. 2011; 12: 735-42. doi:10.1016/S1470-2045(11)70184-X.

61. Rosell R, Carcereny E, Gervais R, Vergnenegre A, Massuti B, Felip E, et al. Erlotinib versus standard chemotherapy as first-line treatment for European patients with advanced EGFR mutation-positive non-small-cell lung cancer (EURTAC): a multicentre, open-label, randomised phase 3 trial. Lancet Oncol, 2012; 13: 239-46. doi:10.1016/S1470-2045(11)70393-X.

62. Pallis AG, Voutsina A, Kentepozidis N, Giassas S, Papakotoulas P, Agelaki S, et al. A phase II trial of erlotinib as front-line treatment in clinically selected patients with non-small-cell lung cancer. Clin Lung Cancer. 2012; 13: 129-35. doi:10.1016/j.cllc.2011.08.004.

63. Choi DR, Lee DH, Choi CM, Kim SW, Suh C, Lee JS. Erlotinib in first-line therapy for non-small cell lung cancer: a prospective phase II study. Anticancer Res. 2011; 31: 3457-62. doi:31/10/3457 [pii]

64. Ku GY, Haaland BA, de Lima Lopes G, Jr. Gefitinib vs. chemotherapy as first-line therapy in advanced non-small cell lung cancer: meta-analysis of phase III trials. Lung Cancer. 2011; 74: 469-73. doi:10.1016/j.lungcan.2011.04.008.

65. Gao G, Ren S, Li A, Xu J, Xu O Su C, et al. Epidermal growth factor receptor-tyrosine kinase inhibitor therapy is effective as first-line treatment of advanced non-small-cell lung cancer with mutated EGFR: A meta-analysis from six phase III randomized controlled trials. Int J Cancer. 2012; 131: E822-9. doi:10.1002/ijc.27396.

66. Kosaka T, Yamaki E, Mogi A, Kuwano H. Mechanisms of resistance to EGFR TKIs and development of a new generation of drugs in non-small-cell lung cancer. J Biomed Biotechnol. 2011; 2011: 165214. doi:10.1155/2011/165214.

67. Pietanza MC, Gadgeel SM, Dowlati A, Lynch TJ, Salgia R, Rowland KM, Jr., et al. Phase II study of the multitargeted tyrosine kinase inhibitor XL647 in patients with non-small-cell lung cancer. J Thorac Oncol. 2012; 7: 856-65. doi:10.1097/JTO.0b013e31824c943f.

68. Carillio G, Montanino A, Costanzo R, Sandomenico C, Piccirillo MC, Di Maio $\mathrm{M}$, et al. Cetuximab in non-small-cell lung cancer. Expert Rev Anticancer Ther. 2012: 12: 163-75, doi:10.1586/era.11.178.

69. Ibrahim EM, Abouelkhair KM, Al-Masri OA, Chaudry NC, Kazkaz GA. Cetuximab-based therapy is effective in chemotherapy-naive patients with advanced and metastatic non-small-cell lung cancer: a meta-analysis of randomized controlled trials. Lung. 2011; 189: 193-8. doi:10.1007/s00408-011-9286-3.

70. Yap TA, Vidal L, Adam J, Stephens P, Spicer J, Shaw H, et al. Phase I trial of the irreversible EGFR and HER2 kinase inhibitor BIBW 2992 in patients with advanced solid tumors. J Clin Oncol. 2010; 28: 3965-72. doi:10.1200/JCO.2009.26.7278.

71. Murakami H, Tamura T, Takahashi T, Nokihara H, Naito T, Nakamura $Y$, et al. Phase I study of continuous afatinib (BIBW 2992) in patients with advanced non-small cell lung cancer after prior chemotherapy/erlotinib/gefitinib (LUX-Lung 4). Cancer Chemother Pharmacol. 2012; 69: 891-9. doi:10.1007/s00280-011-1738-1.

72. Metro G, Crino L. The LUX-Lung clinical trial program of afatinib for non-small-cell lung cancer. Expert Rev Anticancer Ther. 2011; 11: 673-82. doi:10.1586/era.11.34.

73. Hirsh V, Cadranel J, Cong XJ, Fairclough D, Finnern HW, Lorence RM, et al. Symptom and Quality of Life Benefit of Afatinib in Advanced Non-Small-Cell Lung Cancer Patients Previously Treated with Erlotinib or Gefitinib: Results of a Randomized Phase IIb/III Trial (LUX-Lung 1). J Thorac Oncol. 2013; 8: 229-37. doi:10.1097/JTO.0b013e3182773fce.

74. Yang JC, Shih JY, Su WC, Hsia TC, Tsai CM, Ou SH, et al. Afatinib for patients with lung adenocarcinoma and epidermal growth factor receptor mutations (LUX-Lung 2): a phase 2 trial. Lancet Oncol. 2012; 13: 539-48. doi:10.1016/S1470-2045(12)70086-4.

75. Miller VA, Hirsh V, Cadranel J, Chen YM, Park K, Kim SW, et al. Afatinib versus placebo for patients with advanced, metastatic non-small-cell lung cancer after failure of erlotinib, gefitinib, or both, and one or two lines of chemotherapy (LUX-Lung 1): a phase $2 b / 3$ randomised trial. Lancet Oncol. 2012; 13: 528-38. doi:10.1016/S1470-2045(12)70087-6.

76. Sequist LV, Yang JC, Yamamoto N, O'Byrne K, Hirsh V, Mok T, et al. Phase III Study of Afatinib or Cisplatin Plus Pemetrexed in Patients With Metastatic Lung Adenocarcinoma With EGFR Mutations. J Clin Oncol. 2013. doi:10.1200/JCO.2012.44.2806.

77. Rossi A, Pasquale R, Esposito C, Normanno N. Should epidermal growth factor receptor tyrosine kinase inhibitors be considered ideal drugs for the treatment of selected advanced non-small cell lung cancer patients? Cancer Treat Rev. 2012. doi:10.1016/j.ctrv.2012.09.001.

78. Lee JS, Scott C, Komaki R, Fossella FV, Dundas GS, McDonald S, et al. Concurrent chemoradiation therapy with oral etoposide and cisplatin for locally advanced inoperable non-small-cell lung cancer: radiation therapy oncology group protocol 91-06. J Clin Oncol. 1996; 14: 1055-64.

79. Gandara DR, Chansky K, Albain KS, Leigh BR, Gaspar LE, Lara PN, Jr., et al. Consolidation docetaxel after concurrent chemoradiotherapy in stage IIIB non-small-cell lung cancer: phase II Southwest Oncology Group Study S9504. J Clin Oncol. 2003; 21: 2004-10. doi:10.1200/JCO.2003.04.197.
80. Choy H. Combination chemoradiotherapy with gemcitabine: potential applications. Oncology (Williston Park). 2000; 14: 20-5.

81. Komaki R, Scott C, Ettinger D, Lee JS, Fossella FV, Curran W, et al. Randomized study of chemotherapy/radiation therapy combinations for favorable patients with locally advanced inoperable nonsmall cell lung cancer: Radiation Therapy Oncology Group (RTOG) 92-04. Int J Radiat Oncol Biol Phys. 1997: 38: 149-55.

82. Komaki R, Scott C, Lee JS, Urtasun RC, Byhardt RW, Emami B, et al. Impact of adding concurrent chemotherapy to hyperfractionated radiotherapy for locally advanced non-small cell lung cancer (NSCLC): comparison of RTOG 83-11 and RTOG 91-06. American journal of clinical oncology. 1997; 20: 435-40.

83. Furuse K, Fukuoka M, Kawahara M, Nishikawa H, Takada Y, Kudoh S, et al. Phase III study of concurrent versus sequential thoracic radiotherapy in combination with mitomycin, vindesine, and cisplatin in unresectable stage III non-small-cell lung cancer. J Clin Oncol. 1999; 17: 2692-9.

84. Rothschild S, Bucher SE, Bernier J, Aebersold DM, Zouhair A, Ries G, et al. Gefitinib in combination with irradiation with or without cisplatin in patients with inoperable stage III non-small cell lung cancer: a phase I trial. International journal of radiation oncology, biology, physics. 2011; 80: 126-32. doi:10.1016/j.ijrobp.2010.01.048.

85. Ready N, Janne PA, Bogart J, Dipetrillo T, Garst J, Graziano S, et al. Chemoradiotherapy and gefitinib in stage III non-small cell lung cancer with epidermal growth factor receptor and KRAS mutation analysis: cancer and leukemia group B (CALEB) 30106, a CALGB-stratified phase II trial. J Thorac Oncol. 2010; 5: 1382-90. doi:10.1097/JTO.0b013e3181eba657.

86. Center B, Petty WJ, Ayala D, Hinson WH, Lovato J, Capellari J, et al. A phase I study of gefitinib with concurrent dose-escalated weekly docetaxel and conformal three-dimensional thoracic radiation followed by consolidative docetaxel and maintenance gefitinib for patients with stage III non-small cell lung cancer. J Thorac Oncol. 2010; 5: 69-74. doi:10.1097/JTO.0b013e3181c59a0e.

87. Wang J, Xia TY, Wang YJ, Li HQ, Li P, Wang JD, et al. Prospective study of epidermal growth factor receptor tyrosine kinase inhibitors concurrent with individualized radiotherapy for patients with locally advanced or metastatic non-small-cell lung cancer. International journal of radiation oncology, biology, physics. 2011; 81: e59-65. doi:10.1016/j.ijrobp.2010.12.035.

88. Chang CC, Chi KH, Kao SJ, Hsu PS, Tsang YW, Chang HJ, et al. Upfront gefitinib/erlotinib treatment followed by concomitant radiotherapy for advanced lung cancer: a mono-institutional experience. Lung Cancer. 2011; 73: 189-94. doi:10.1016/j.lungcan.2010.12.007.

89. Imai H, Shukuya T, Takahashi T, Fujiwara S, Mori K, Ono A, et al. Comparison of the Time-to-response Between Radiotherapy and Epidermal Growth Factor Receptor - Tyrosine Kinase Inhibitors for Advanced Non-small Cell Lung Cancer with EGFR Mutation. Anticancer Res. 2013; 33: 3279-84.

90. Sequist LV, Besse B, Lynch TJ, Miller VA, Wong KK, Gitlitz B, et al. Neratinib, an irreversible pan-ErbB receptor tyrosine kinase inhibitor: results of a phase II trial in patients with advanced non-small-cell lung cancer. J Clin Oncol. 2010; 28: 3076-83. doi:10.1200/JCO.2009.27.9414.

91. Ramalingam SS, Blackhall F, Krzakowski M, Barrios CH, Park K, Bover I, et al. Randomized phase II study of dacomitinib (PF-00299804), an irreversible pan-human epidermal growth factor receptor inhibitor, versus erlotinib in patients with advanced non-small-cell lung cancer. J Clin Oncol. 2012; 30: 3337-44. doi:10.1200/JCO.2011.40.9433.

92. Patil N, Abba M, Allgayer H. Cetuximab and biomarkers in non-small-cell lung carcinoma. Biologics. 2012; 6: 221-31. doi:10.2147/BTT.S24217.

93. Butts CA, Bodkin D, Middleman EL, Englund CW, Ellison D, Alam Y, et al. Randomized phase II study of gemcitabine plus cisplatin or carboplatin [corrected], with or without cetuximab, as first-line therapy for patients with advanced or metastatic non small-cell lung cancer. J Clin Oncol. 2007; 25: 5777-84. doi:10.1200/JCO.2007.13.0856.

94. Rosell R, Robinet G, Szczesna A, Ramlau R, Constenla M, Mennecier BC, et al. Randomized phase II study of cetuximab plus cisplatin/vinorelbine compared with cisplatin/vinorelbine alone as first-line therapy in EGFR-expressing advanced non-small-cell lung cancer. Ann Oncol. 2008; 19: 362-9. doi:10.1093/annonc/mdm474.

95. Lynch TJ, Patel T, Dreisbach L, McCleod M, Heim WJ, Hermann RC, et al. Cetuximab and first-line taxane/carboplatin chemotherapy in advanced non-small-cell lung cancer: results of the randomized multicenter phase III trial BMS099. J Clin Oncol. 2010; 28: 911-7. doi:10.1200/JCO.2009.21.9618.

96. Khambata-Ford S, Harbison CT, Hart LL, Awad M, Xu LA, Horak CE, et al. Analysis of potential predictive markers of cetuximab benefit in BMS099, a phase III study of cetuximab and first-line taxane/carboplatin in advanced non-small-cell lung cancer. J Clin Oncol. 2010; 28: 918-27. doi:10.1200/JCO.2009.25.2890.

97. Hirsch FR, Herbst RS, Olsen C, Chansky K, Crowley J, Kelly K, et al. Increased EGFR gene copy number detected by fluorescent in situ hybridization predicts outcome in non-small-cell lung cancer patients treated with cetuximab and chemotherapy. J Clin Oncol. 2008; 26: 3351-7. doi:10.1200/JCO.2007.14.0111.

98. Pirker R, Pereira JR, Szczesna A, von Pawel J, Krzakowski M, Ramlau R, et al. Prognostic factors in patients with advanced non-small cell lung cancer: data from the phase III FLEX study. Lung Cancer. 2012; 77: 376-82. doi:10.1016/j.lungcan.2012.03.010.

99. Hanna N, Lilenbaum R, Ansari R, Lynch T, Govindan R, Janne PA, et al. Phase II trial of cetuximab in patients with previously treated non-small-cell lung cancer. J Clin Oncol. 2006; 24: 5253-8. doi:10.1200/JCO.2006.08.2263. 
100. Lin H, Jiang J, Liang X, Zhou X, Huang R. Chemotherapy with cetuximab or chemotherapy alone for untreated advanced non-small-cell lung cancer: a systematic review and meta-analysis. Lung Cancer. 2010; 70: 57-62. doi:10.1016/j.lungcan.2010.01.009.

101. Turke AB, Zejnullahu K, Wu YL, Song Y, Dias-Santagata D, Lifshits E, et al. Preexistence and clonal selection of MET amplification in EGFR mutant NSCLC. Cancer cell. 2010; 17: 77-88. doi:10.1016/j.ccr.2009.11.022.

102. Belalcazar A, Azana D, Perez CA, Raez LE, Santos ES. Targeting the Met pathway in lung cancer. Expert Rev Anticancer Ther. 2012; 12: 519-28. doi:10.1586/era.12.16.

103. Goldman JW, Laux I, Chai F, Savage RE, Ferrari D, Garmey EG, et al. Phase 1 dose-escalation trial evaluating the combination of the selective MET (mesenchymal-epithelial transition factor) inhibitor tivantinib (ARQ 197) plus erlotinib. Cancer. 2012; 118: 5903-11. doi:10.1002/cncr.27575.

104. Sequist LV, von Pawel J, Garmey EG, Akerley WL, Brugger W, Ferrari D, et al. Randomized phase II study of erlotinib plus tivantinib versus erlotinib plus placebo in previously treated non-small-cell lung cancer. J Clin Oncol. 2011; 29: 3307-15. doi:10.1200/JCO.2010.34.0570.

105. Scagliotti GV, Novello S, Schiller JH, Hirsh V, Sequist LV, Soria JC, et al. Rationale and design of MARQUEE: a phase III, randomized, double-blind study of tivantinib plus erlotinib versus placebo plus erlotinib in previously treated patients with locally advanced or metastatic, nonsquamous, non-small-cell lung cancer. Clin Lung Cancer. 2012; 13: 391-5. doi:10.1016/j.cllc.2012.01.003.

106. Chang JW, Liu HP, Hsieh MH, Fang YF, Hsieh MS, Hsieh JJ, et al. Increased epidermal growth factor receptor (EGFR) gene copy number is strongly associated with EGFR mutations and adenocarcinoma in non-small cell lung cancers: a chromogenic in situ hybridization study of 182 patients. Lung Cancer. 2008; 61: 328-39. doi:10.1016/j.lungcan.2008.01.009.

107. Sasaki H, Endo K, Okuda K, Kawano O, Kitahara N, Tanaka H, et al. Epidermal growth factor receptor gene amplification and gefitinib sensitivity in patients with recurrent lung cancer. J Cancer Res Clin Oncol. 2008; 134: 569-77. doi:10.1007/s00432-007-0320-z.

108. Suzuki Y, Orita M, Shiraishi M, Hayashi K, Sekiya T. Detection of ras gene mutations in human lung cancers by single-strand conformation polymorphism analysis of polymerase chain reaction products. Oncogene. 1990; 5: 1037-43.

109. Schiller JH, Adak S, Feins RH, Keller SM, Fry WA, Livingston RB, et al. Lack of prognostic significance of p53 and K-ras mutations in primary resected non-small-cell lung cancer on E4592: a Laboratory Ancillary Study on an Eastern Cooperative Oncology Group Prospective Randomized Trial of Postoperative Adjuvant Therapy. J Clin Oncol. 2001; 19: 448-57.

110. Aviel-Ronen S, Blackhall FH, Shepherd FA, Tsao MS. K-ras mutations in non-small-cell lung carcinoma: a review. Clin Lung Cancer. 2006; 8: 30-8. doi:10.3816/CLC.2006.n.030.

111. Linardou H, Dahabreh IJ, Kanaloupiti D, Siannis F, Bafaloukos D, Kosmidis P, et al. Assessment of somatic k-RAS mutations as a mechanism associated with resistance to EGFR-targeted agents: a systematic review and meta-analysis of studies in advanced non-small-cell lung cancer and metastatic colorectal cancer. Lancet Oncol. 2008; 9: 962-72. doi:10.1016/S1470-2045(08)70206-7.

112. Califano R, Landi L, Cappuzzo F. Prognostic and predictive value of K-RAS mutations in non-small cell lung cancer. Drugs. 2012; 72 Suppl 1: 28-36. doi:10.2165/1163012-S0-000000000-00000.

113. Mao C, Qiu LX, Liao RY, Du FB, Ding H, Yang WC, et al. KRAS mutations and resistance to EGFR-TKIs treatment in patients with non-small cell lung cancer: a meta-analysis of 22 studies. Lung Cancer. 2010; 69: 272-8. doi:10.1016/j.lungcan.2009.11.020

114. Cadranel J, Mauguen A, Faller M, Zalcman G, Buisine MP, Westeel V, et al. Impact of systematic EGFR and KRAS mutation evaluation on progression-free survival and overall survival in patients with advanced non-small-cell lung cancer treated by erlotinib in a French prospective cohort (ERMETIC project--part 2). J Thorac Oncol. 2012; 7: 1490-502. doi:10.1097/JTO.0b013e318265b2b5.

115. Papadimitrakopoulou V. Development of PI3K/AKT/mTOR pathway inhibitors and their application in personalized therapy for non-small-cell lung cancer. J Thorac Oncol. 2012; 7: 1315-26. doi:10.1097/JTO.0b013e31825493eb.

116. Gridelli C, Maione P, Rossi A. The potential role of mTOR inhibitors in non-small cell lung cancer. Oncologist. 2008; 13: 139-47. doi:10.1634/theoncologist.2007-0171.

117. Papadimitrakopoulou VA, Soria JC, Jappe A, Jehl V, Klimovsky J, Johnson BE. Everolimus and erlotinib as second- or third-line therapy in patients with advanced non-small-cell lung cancer. J Thorac Oncol. 2012; 7: 1594-601. doi:10.1097/JTO.0b013e3182614835.

118. Ramalingam SS, Owonikoko TK, Behera M, Subramanian J, Saba NF, Kono SA, et al. Phase II study of docetaxel in combination with everolimus for second- or third-line therapy of advanced non-small-cell lung cancer. J Thorac Oncol. 2013; 8: 369-72. doi:10.1097/JTO.0b013e318282709c

119. Dong S, Zhang XC, Cheng H, Zhu JQ, Chen ZH, Zhang YF, et al. Everolimus synergizes with gefitinib in non-small-cell lung cancer cell lines resistant to epidermal growth factor receptor tyrosine kinase inhibitors. Cancer Chemother Pharmacol. 2012; 70: 707-16. doi:10.1007/s00280-012-1946-3.

120. Donev IS, Wang W, Yamada T, Li Q, Takeuchi S, Matsumoto K, et al. Transient PI3K inhibition induces apoptosis and overcomes HGF-mediated resistance to
EGFR-TKIs in EGFR mutant lung cancer. Clin Cancer Res. 2011; 17: 2260-9. doi:10.1158/1078-0432.CCR-10-1993.

121. Heavey S, O'Byrne KJ, Gately K. Strategies for co-targeting the PI3K/AKT/mTOR pathway in NSCLC. Cancer Treat Rev. 2013. doi:10.1016/j.ctrv.2013.08.006.

122. Zhang Y, Ni HJ, Cheng DY. Prognostic value of phosphorylated mTOR/RPS6KB1 in non- small cell lung cancer. Asian Pac J Cancer Prev. 2013; 14: $3725-8$.

123. Gridelli C, Solange P, Sgambato A, Casaluce F, Adjei AA, Ciardiello F. ALK inhibitors in the treatment of advanced NSCLC. Cancer Treat Rev. 2013. doi:10.1016/j.ctrv.2013.07.002.

124. Kimura H, Nakajima T, Takeuchi $K$, Soda M, Mano H, Iizasa T, et al. ALK fusion gene positive lung cancer and 3 cases treated with an inhibitor for ALK kinase activity. Lung Cancer. 2012; 75: 66-72. doi:10.1016/j.lungcan.2011.05.027.

125. Herbst RS, Heymach JV, Lippman SM. Lung cancer. N Engl J Med. 2008; 359: 1367-80. doi:10.1056/NEJMra0802714

126. Solomon B, Varella-Garcia M, Camidge DR. ALK gene rearrangements: a new therapeutic target in a molecularly defined subset of non-small cell lung cancer. J Thorac Oncol. 2009; 4: 1450-4. doi:10.1097/JTO.0b013e3181c4dedb

127. Pilotto S, Peretti U, Novello S, Rossi G, Milella M, Giaj Levra M, et al. PROFILing non-small-cell lung cancer patients for treatment with crizotinib according to anaplastic lymphoma kinase abnormalities: translating science into medicine. Expert Opin Pharmacother. 2013; 14: 597-608. doi:10.1517/14656566.2013.778828.

128. Camidge DR, Bang YJ, Kwak EL, Iafrate AJ, Varella-Garcia M, Fox SB, et al. Activity and safety of crizotinib in patients with ALK-positive non-small-cell lung cancer: updated results from a phase 1 study. Lancet Oncol. 2012; 13: 1011-9. doi:10.1016/S1470-2045(12)70344-3

129. Seto T, Kiura K, Nishio M, Nakagawa K, Maemondo $M$, Inoue A, et al. $\mathrm{CH} 5424802$ (RO5424802) for patients with ALK-rearranged advanced non-small-cell lung cancer (AF-001JP study): a single-arm, open-label, phase 1-2 study. Lancet Oncol. 2013; 14: 590-8. doi:10.1016/S1470-2045(13)70142-6.

130. Shaw AT, Yeap BY, Solomon BJ, Riely GJ, Gainor J, Engelman JA, et al. Effect of crizotinib on overall survival in patients with advanced non-small-cell lung cancer harbouring ALK gene rearrangement: a retrospective analysis. Lancet Oncol. 2011; 12: 1004-12. doi:10.1016/S1470-2045(11)70232-7.

131. Chen X, Zhou JY, Zhao J, Chen JJ, Ma SN. Crizotinib overcomes hepatocyte growth factor-mediated resistance to gefitinib in EGFR-mutant non-small-cell lung cancer cells. Anticancer Drugs. 2013. doi:10.1097/CAD.0000000000000011.

132. Sachdev D, Yee D. The IGF system and breast cancer. Endocrine-related cancer. 2001; 8: 197-209.

133. Pollak MN. Insulin-like growth factors and neoplasia. Novartis Foundation symposium. 2004; 262: 84-98; discussion -107, 265-8.

134. Morgillo F, Kim WY, Kim ES, Ciardiello F, Hong WK, Lee HY. Implication of the insulin-like growth factor-IR pathway in the resistance of non-small cell lung cancer cells to treatment with gefitinib. Clin Cancer Res. 2007; 13: 2795-803. doi:10.1158/1078-0432.CCR-06-2077.

135. Choi YJ, Rho JK, Jeon BS, Choi SJ, Park SC, Lee SS, et al. Combined inhibition of IGFR enhances the effects of gefitinib in H1650: a lung cancer cell line with EGFR mutation and primary resistance to EGFR-TK inhibitors. Cancer Chemother Pharmacol. 2010; 66: 381-8. doi:10.1007/s00280-009-1174-7.

136. Weickhardt A, Doebele R, Oton A, Lettieri J, Maxson D, Reynolds M, et al. A phase I/II study of erlotinib in combination with the anti-insulin-like growth factor-1 receptor monoclonal antibody IMC-A12 (cixutumumab) in patients with advanced non-small cell lung cancer. J Thorac Oncol. 2012; 7: 419-26. doi:10.1097/JTO.0b013e31823c5b11.

137. Goto $\mathrm{Y}$, Sekine I, Tanioka M, Shibata $\mathrm{T}$, Tanai $\mathrm{C}$, Asahina $\mathrm{H}$, et al. Figitumumab combined with carboplatin and paclitaxel in treatment-naive Japanese patients with advanced non-small cell lung cancer. Investigational new drugs. 2012; 30: 1548-56. doi:10.1007/s10637-011-9715-4.

138. Gualberto A, Hixon ML, Karp DD, Li D, Green S, Dolled-Filhart M, et al. Pre-treatment levels of circulating free IGF-1 identify NSCLC patients who derive clinical benefit from figitumumab. Br J Cancer. 2011; 104: 68-74. doi:10.1038/sj.bjc.6605972.

139. Ramalingam SS, Spigel DR, Chen D, Steins MB, Engelman JA, Schneider CP, et al. Randomized phase II study of erlotinib in combination with placebo or R1507, a monoclonal antibody to insulin-like growth factor-1 receptor, for advanced-stage non-small-cell lung cancer. J Clin Oncol. 2011; 29: 4574-80. doi:10.1200/JCO.2011.36.6799.

140. Pallis AG, Christofillakis C, Tselepatiotis E, Agelaki S, Vamvakas L, Souglakos $\mathrm{J}$, et al. Sequential administration of docetaxel followed by maintenance gefitinib, as salvage treatment in patients with advanced NSCLC: a multicenter phase II trial. Lung Cancer. 2007; 55: 101-7. doi:10.1016/j.lungcan.2006.08.019

141. Cufer T, Vrdoljak E, Gaafar R, Erensoy I, Pemberton K. Phase II, open-label, randomized study (SIGN) of single-agent gefitinib (IRESSA) or docetaxel as second-line therapy in patients with advanced (stage IIIb or IV) non-small-cell lung cancer. Anticancer Drugs. 2006; 17: 401-9. doi:10.1097/01.cad.0000203381.99490.ab.

142. Maruyama R, Nishiwaki $Y$, Tamura T, Yamamoto N, Tsuboi M, Nakagawa K, et al. Phase III study, V-15-32, of gefitinib versus docetaxel in previously treated Japanese patients with non-small-cell lung cancer. J Clin Oncol. 2008; 26: 4244-52. doi:10.1200/JCO.2007.15.0185 
143. Sekine I, Ichinose Y, Nishiwaki Y, Yamamoto N, Tsuboi M, Nakagawa K, et al. Quality of life and disease-related symptoms in previously treated Japanese patients with non-small-cell lung cancer: results of a randomized phase III study (V-15-32) of gefitinib versus docetaxel. Ann Oncol. 2009; 20: 1483-8. doi:10.1093/annonc/mdp031.

144. Lee DH, Park K, Kim JH, Lee JS, Shin SW, Kang JH, et al. Randomized Phase III trial of gefitinib versus docetaxel in non-small cell lung cancer patients who have previously received platinum-based chemotherapy. Clin Cancer Res. 2010; 16: 1307-14. doi:10.1158/1078-0432.CCR-09-1903.

145. Morere JF, Brechot JM, Westeel V, Gounant V, Lebeau B, Vaylet F, et al. Randomized phase II trial of gefitinib or gemcitabine or docetaxel chemotherapy in patients with advanced non-small-cell lung cancer and a performance status of 2 or 3 (IFCT-0301 study). Lung Cancer. 2010; 70: 301-7. doi:10.1016/j.lungcan.2010.03.003.

146. Kim ES, Hirsh V, Mok T, Socinski MA, Gervais R, Wu YL, et al. Gefitinib versus docetaxel in previously treated non-small-cell lung cancer (INTEREST): a randomised phase III trial. Lancet. 2008; 372: 1809-18. doi:10.1016/S0140-6736(08)61758-4.

147. Douillard JY, Shepherd FA, Hirsh V, Mok T, Socinski MA, Gervais R, et al. Molecular predictors of outcome with gefitinib and docetaxel in previously treated non-small-cell lung cancer: data from the randomized phase III INTEREST trial. J Clin Oncol. 2010; 28: 744-52. doi:10.1200/JCO.2009.24.3030.

148. Cromwell I, van der Hoek K, Melosky B, Peacock S. Erlotinib or docetaxel for second-line treatment of non-small cell lung cancer: a real-world cost-effectiveness analysis. J Thorac Oncol. 2011; 6: 2097-103. doi:10.1097/JTO.0b013e31822f657a.

149. Krawczyk P, Kowalski DM, Wojas-Krawczyk K, Mlak R, Jaskiewicz P, Kucharczyk T, et al. The qualification of docetaxel or erlotinib for second-line therapy should be based on clinical and molecular predictive factors. Chemotherapy. 2012; 58: 60-9. doi:10.1159/000336143.

150. Kim ST, Uhm JE, Lee J, Sun JM, Sohn I, Kim SW, et al. Randomized phase II study of gefitinib versus erlotinib in patients with advanced non-small cell lung cancer who failed previous chemotherapy. Lung Cancer. 2012; 75: 82-8. doi:10.1016/j.lungcan.2011.05.022.

151. Fan WC, Yu CJ, Tsai CM, Huang MS, Lai CL, Hsia TC, et al. Different efficacies of erlotinib and gefitinib in taiwanese patients with advanced non-small cell lung cancer: a retrospective multicenter study. J Thorac Oncol. 2011; 6: 148-55. doi:10.1097/JTO.0b013e3181f77b27.

152. Shao YY, Shau WY, Lin ZZ, Chen HM, Kuo R, Yang JC, et al. Comparison of gefitinib and erlotinib efficacies as third-line therapy for advanced non-small-cell lung cancer. Eur J Cancer. 2013; 49: 106-14. doi:10.1016/j.ejca.2012.07.014

153. Herbst RS, Prager D, Hermann R, Fehrenbacher L, Johnson BE, Sandler A, et al. TRIBUTE: a phase III trial of erlotinib hydrochloride (OSI-774) combined with carboplatin and paclitaxel chemotherapy in advanced non-small-cell lung cancer. J Clin Oncol. 2005; 23: 5892-9. doi:10.1200/JCO.2005.02.840.

154. Natale RB, Bodkin D, Govindan R, Sleckman BG, Rizvi NA, Capo A, et al. Vandetanib versus gefitinib in patients with advanced non-small-cell lung cancer: results from a two-part, double-blind, randomized phase ii study. J Clin Oncol. 2009; 27: 2523-9. doi:10.1200/JCO.2008.18.6015.

155. Hong J, Kyung SY, Lee SP, Park JW, Jung SH, Lee JI, et al. Pemetrexed versus gefitinib versus erlotinib in previously treated patients with non-small cell lung cancer. Korean J Intern Med. 2010; 25: 294-300. doi:10.3904/ kjim.2010.25.3.294.

156. Lee DH, Kim SW, Suh C, Yoon DH, Yi EJ, Lee JS. Phase II study of erlotinib as a salvage treatment for non-small-cell lung cancer patients after failure of gefitinib treatment. Ann Oncol. 2008; 19: 2039-42. doi:10.1093/annonc/mdn423.

157. Zhou ZT, Xu XH, Wei Q, Lu MQ, Wang J, Wen $\mathrm{CH}$. Erlotinib in advanced non-small-cell lung cancer after gefitinib failure. Cancer Chemother Pharmacol. 2009; 64: 1123-7. doi:10.1007/s00280-009-0973-1.

158. Cho BC, Im CK, Park MS, Kim SK, Chang J, Park JP, et al. Phase II study of erlotinib in advanced non-small-cell lung cancer after failure of gefitinib. J Clin Oncol. 2007; 25: 2528-33. doi:10.1200/JCO.2006.10.4166.

159. Wong MK, Lo AI, Lam B, Lam WK, Ip MS, Ho JC. Erlotinib as salvage treatment after failure to first-line gefitinib in non-small cell lung cancer. $\begin{array}{lllll}\text { Cancer Chemother } & \text { 2010; 65: }\end{array}$ doi:10.1007/s00280-009-1107-5.

160. Tsujino K, Kawaguchi T, Kubo A, Aono N, Nakao K, Koh Y, et al. Response rate is associated with prolonged survival in patients with advanced non-small cell lung cancer treated with gefitinib or erlotinib. J Thorac Oncol. 2009; 4: 994-1001. doi:10.1097/JTO.0b013e3181a94a2f.

161. Gridelli C, Maione P, Castaldo V, Rossi A. Gefitinib in elderly and unfit patients affected by advanced non-small-cell lung cancer. Br J Cancer. 2003; 89: 1827-9. doi:10.1038/sj.bjc.6601387.

162. Cappuzzo F, Bartolini S, Ceresoli GL, Tamberi S, Spreafico A, Lombardo L, et al. Efficacy and tolerability of gefitinib in pretreated elderly patients with advanced non-small-cell lung cancer (NSCLC). Br J Cancer. 2004; 90: 82-6. doi: 10.1038 /sj.bjc. 6601470

163. Oshita F, Yamada K, Saito H, Noda K. Phase II study of nedaplatin and irinotecan followed by gefitinib for elderly patients with unresectable non-small cell lung cancer. Cancer Chemother Pharmacol. 2008; 62: 465-70. doi:10.1007/s00280-007-0626-1.

164. Simon GR, Extermann M, Chiappori A, Williams CC, Begum M, Kapoor R, et al. Phase 2 trial of docetaxel and gefitinib in the first-line treatment of patients with advanced nonsmall-cell lung cancer (NSCLC) who are 70 years of age or older. Cancer. 2008; 112: 2021-9. doi:10.1002/cncr.23360.

165. Stinchcombe TE, Buzkova P, Choksi J, Taylor M, Bakri K, Gillenwater H, et al. A phase I/II trial of weekly docetaxel and gefitinib in elderly patients with stage IIIB/IV non-small cell lung cancer. Lung Cancer. 2006; 52: 305-11. doi:10.1016/j.lungcan.2006.03.002.

166. Stinchcombe TE, Peterman AH, Lee CB, Moore DT, Beaumont JL, Bradford DS, et al. A randomized phase II trial of first-line treatment with gemcitabine, erlotinib, or gemcitabine and erlotinib in elderly patients (age $>/=70$ years) with stage IIIB/IV non-small cell lung cancer. J Thorac Oncol. 2011; 6: 1569-77. doi:10.1097/JTO.0b013e3182210430.

167. Crino L, Cappuzzo F, Zatloukal P, Reck M, Pesek M, Thompson JC, et al. Gefitinib versus vinorelbine in chemotherapy-naive elderly patients with advanced non-small-cell lung cancer (INVITE): a randomized, phase II study. J Clin Oncol. 2008; 26: 4253-60. doi:10.1200/JCO.2007.15.0672.

168. Maemondo M, Minegishi Y, Inoue A, Kobayashi K, Harada M, Okinaga S, et al. First-line gefitinib in patients aged 75 or older with advanced non-small cell lung cancer harboring epidermal growth factor receptor mutations: NEJ 003 study. J Thorac Oncol. 2012; 7: 1417-22. doi:10.1097/JTO.0b013e318260de8b.

169. Ebi N, Semba H, Tokunaga SJ, Takayama K, Wataya H, Kuraki T, et al. A phase II trial of gefitinib monotherapy in chemotherapy-naive patients of 75 years or older with advanced non-small cell lung cancer. J Thorac Oncol. 2008; 3: 1166-71. doi:10.1097/JTO.0b013e318186a88d.

170. LeCaer H, Greillier L, Corre R, Jullian H, Crequit J, Falchero L, et al. A multicenter phase II randomized trial of gemcitabine followed by erlotinib at progression, versus the reverse sequence, in vulnerable elderly patients with advanced non small-cell lung cancer selected with a comprehensive geriatric assessment (the GFPC 0505 study). Lung Cancer. 2012; 77: 97-103. doi:10.1016/j.lungcan.2012.02.004

171. Chen YM, Tsai CM, Fan WC, Shih JF, Liu SH, Wu CH, et al. Phase II randomized trial of erlotinib or vinorelbine in chemonaive, advanced, non-small cell lung cancer patients aged 70 years or older. J Thorac Oncol. 2012; 7: 412-8. doi:10.1097/JTO.0b013e31823a39e8.

172. LeCaer H, Barlesi F, Corre R, Jullian H, Bota S, Falchero L, et al. A multicentre phase II randomised trial of weekly docetaxel/gemcitabine followed by erlotinib on progression, vs the reverse sequence, in elderly patients with advanced non small-cell lung cancer selected with a comprehensive geriatric assessment (the GFPC 0504 study). Br J Cancer. 2011; 105: 1123-30. doi:10.1038/bjc.2011.331

173. Rossi D, Dennetta D, Ugolini M, Catalano V, Alessandroni P, Giordani P, et al. Activity and safety of erlotinib as second- and third-line treatment in elderly patients with advanced non-small cell lung cancer: a phase II trial. Target Oncol. 2010; 5: 231-5. doi:10.1007/s11523-010-0163-4.

174. Wheatley-Price P, Ding K, Seymour L, Clark GM, Shepherd FA. Erlotinib for advanced non-small-cell lung cancer in the elderly: an analysis of the National Cancer Institute of Canada Clinical Trials Group Study BR.21. J Clin Oncol. 2008; 26: 2350-7. doi:10.1200/JCO.2007.15.2280.

175. Vadakara J, Borghaei H. Personalized medicine and treatment approaches in non-small-cell lung carcinoma. Pharmgenomics Pers Med. 2012; 5: 113-23. doi:10.2147/PGPM.S24258.

176. Folkman J. What is the evidence that tumors are angiogenesis dependent? J Natl Cancer Inst. 1990; 82: 4-6.

177. Ferrara N. The role of vascular endothelial growth factor in pathological angiogenesis. Breast Cancer Res Treat. 1995; 36: 127-37.

178. Niho $\mathrm{S}$, Kunitoh $\mathrm{H}$, Nokihara $\mathrm{H}$, Horai $\mathrm{T}$, Ichinose $\mathrm{Y}$, Hida $\mathrm{T}$, et al. Randomized phase II study of first-line carboplatin-paclitaxel with or without bevacizumab in Japanese patients with advanced non-squamous non-small-cell lung cancer. Lung Cancer. 2012; 76: 362-7. doi:10.1016/j.lungcan.2011.12.005.

179. Pallis AG, Syrigos KN. Targeting tumor neovasculature in non-small-cell lung cancer. Crit Rev Oncol Hematol. 2012. doi:10.1016/j.critrevonc.2012.10.003.

180. Braghiroli MI, Sabbaga J, Hoff PM. Bevacizumab: overview of the literature. Expert Rev Anticancer Ther. 2012; 12: 567-80. doi:10.1586/era.12.13.

181. Reck M, von Pawel J, Zatloukal P, Ramlau R, Gorbounova V, Hirsh V, et al. Phase III trial of cisplatin plus gemcitabine with either placebo or bevacizumab as first-line therapy for nonsquamous non-small-cell lung cancer: AVAil. J Clin Oncol. 2009; 27: 1227-34. doi:10.1200/JCO.2007.14.5466.

182. Takeda M, Okamoto I, Yamanaka T, Nakagawa K, Nakanishi Y. Impact of treatment with bevacizumab beyond disease progression: a randomized phase II study of docetaxel with or without bevacizumab after platinum-based chemotherapy plus bevacizumab in patients with advanced nonsquamous non-small cell lung cancer (WJOG 5910L). BMC Cancer. 2012; 12: 327. doi:10.1186/1471-2407-12-327.

183. Lind JS, Senan S, Smit EF. Pulmonary toxicity after bevacizumab and concurrent thoracic radiotherapy observed in a phase I study for inoperable stage III non-small-cell lung cancer. J Clin Oncol. 2012; 30: e104-8. doi:10.1200/JCO.2011.38.4552.

184. Leighl NB, Raez LE, Besse B, Rosen PJ, Barlesi F, Massarelli E, et al. A multicenter, phase 2 study of vascular endothelial growth factor trap (Aflibercept) in platinum- and erlotinib-resistant adenocarcinoma of the lung. J Thorac Oncol. 2010; 5: 1054-9.

185. Ramlau R, Gorbunova V, Ciuleanu TE, Novello S, Ozguroglu M, Goksel T, et al. Aflibercept and Docetaxel versus Docetaxel alone after platinum failure in patients with advanced or metastatic non-small-cell lung cancer: a 
randomized, controlled phase III trial. J Clin Oncol. 2012; 30: 3640-7. doi:10.1200/JCO.2012.42.6932.

186. Scagliotti GV, Krzakowski M, Szczesna A, Strausz J, Makhson A, Reck M, et al. Sunitinib plus erlotinib versus placebo plus erlotinib in patients with previously treated advanced non-small-cell lung cancer: a phase III trial. J Clin Oncol. 2012; 30: 2070-8. doi:10.1200/JCO.2011.39.2993.

187. Dingemans AM, Mellema WW, Groen HJ, van Wijk A, Burgers SA, Kunst PW, et al. A Phase II Study of Sorafenib in Patients with Platinum-Pretreated, Advanced (Stage IIIb or IV) Non-Small Cell Lung Cancer with a KRAS Mutation. Clin Cancer Res. 2013; 19: 743-51. doi:10.1158/1078-0432.CCR-12-1779.

188. Paz-Ares LG, Biesma B, Heigener D, von Pawel J, Eisen T, Bennouna J, et al. Phase III, randomized, double-blind, placebo-controlled trial of gemcitabine/cisplatin alone or with sorafenib for the first-line treatment of advanced, nonsquamous non-small-cell lung cancer. J Clin Oncol. 2012; 30: 3084-92. doi:10.1200/JCO.2011.39.7646.

189. Blumenschein GR, Jr., Kabbinavar F, Menon H, Mok TS, Stephenson J, Beck JT, et al. A phase II, multicenter, open-label randomized study of motesanib or bevacizumab in combination with paclitaxel and carboplatin for advanced nonsquamous non-small-cell lung cancer. Ann Oncol. 2011; 22: 2057-67. doi:10.1093/annonc/mdq731.

190. Scagliotti GV, Vynnychenko I, Park K, Ichinose Y, Kubota K, Blackhall F, et al. International, randomized, placebo-controlled, double-blind phase III study of motesanib plus carboplatin/paclitaxel in patients with advanced nonsquamous non-small-cell lung cancer: MONET1. J Clin Oncol. 2012; 30: 2829-36. doi:10.1200/JCO.2011.41.4987.

191. Heymach JV, Johnson BE, Prager D, Csada E, Roubec J, Pesek M, et al. Randomized, placebo-controlled phase II study of vandetanib plus docetaxel in previously treated non small-cell lung cancer. J Clin Oncol. 2007; 25: 4270-7. doi:10.1200/JCO.2006.10.5122.

192. Wedge SR, Ogilvie DJ, Dukes M, Kendrew J, Chester R, Jackson JA, et al ZD6474 inhibits vascular endothelial growth factor signaling, angiogenesis, and tumor growth following oral administration. Cancer research. 2002; 62: 4645-55.

193. Tamura T, Minami H, Yamada Y, Yamamoto N, Shimoyama T, Murakami H, et al. A phase I dose-escalation study of ZD6474 in Japanese patients with solid, malignant tumors. J Thorac Oncol. 2006; 1: 1002-9.

194. Kiura K, Nakagawa K, Shinkai T, Eguchi K, Ohe Y, Yamamoto N, et al. A randomized, double-blind, phase IIa dose-finding study of Vandetanib (ZD6474) in Japanese patients with non-small cell lung cancer. J Thorac Oncol. 2008; 3: 386-93. doi:10.1097/JTO.0b013e318168d228.

195. Heymach JV, Paz-Ares L, De Braud F, Sebastian M, Stewart DJ, Eberhardt WE, et al. Randomized phase II study of vandetanib alone or with paclitaxel and carboplatin as first-line treatment for advanced non-small-cell lung cancer. J Clin Oncol. 2008; 26: 5407-15. doi:10.1200/JCO.2008.17.3138.

196. de Boer RH, Arrieta O, Yang CH, Gottfried M, Chan V, Raats J, et al. Vandetanib plus pemetrexed for the second-line treatment of advanced non-small-cell lung cancer: a randomized, double-blind phase III trial. J Clin Oncol. 2011; 29: 1067-74. doi:10.1200/JCO.2010.29.5717.

197. Natale RB, Thongprasert S, Greco FA, Thomas M, Tsai CM, Sunpaweravong P, et al. Phase III trial of vandetanib compared with erlotinib in patients with previously treated advanced non-small-cell lung cancer. J Clin Oncol. 2011; 29: 1059-66. doi:10.1200/JCO.2010.28.5981.

198. Lee JS, Hirsh V, Park K, Qin S, Blajman CR, Perng RP, et al. Vandetanib Versus placebo in patients with advanced non-small-cell lung cancer after prior therapy with an epidermal growth factor receptor tyrosine kinase inhibitor: a randomized, double-blind phase III trial (ZEPHYR). J Clin Oncol. 2012; 30: 1114-21. doi:10.1200/JCO.2011.36.1709.

199. Breathnach OS, Freidlin B, Conley B, Green MR, Johnson DH, Gandara DR, et al. Twenty-two years of phase III trials for patients with advanced non-small-cell lung cancer: sobering results. J Clin Oncol. 2001; 19: 1734-42.

200. Lara PN, Jr., Redman MW, Kelly K, Edelman MJ, Williamson SK, Crowley JJ, et al. Disease control rate at 8 weeks predicts clinical benefit in advanced non-small-cell lung cancer: results from Southwest Oncology Group randomized trials. J Clin Oncol. 2008: 26: 463-7. doi:10.1200/JCO.2007.13.0344.

201. Scagliotti GV, Parikh P, von Pawel J, Biesma B, Vansteenkiste J, Manegold C, et al. Phase III study comparing cisplatin plus gemcitabine with cisplatin plus pemetrexed in chemotherapy-naive patients with advanced-stage non-small-cell lung cancer. J Clin Oncol. 2008; 26: 3543-51. doi:10.1200/JCO.2007.15.0375.

202. Reck M, von Pawel J, Zatloukal P, Ramlau R, Gorbounova V, Hirsh V, et al. Overall survival with cisplatin-gemcitabine and bevacizumab or placebo as first-line therapy for nonsquamous non-small-cell lung cancer: results from a randomised phase III trial (AVAiL). Ann Oncol. 2010; 21: 1804-9. doi:10.1093/annonc/mdq020.

203. Joshi M, Jiang Y, Belani CP. Maintenance therapy for advanced non-small-cell lung cancer: switch versus continuation. Expert Opin Pharmacother. 2012; 13: 685-97. doi:10.1517/14656566.2012.668530.

204. Zhang J, Zhang W, Huang S, Li H, Li Y, Chen H, et al. Maintenance erlotinib improves clinical outcomes of unresectable advanced non-small cell lung cancer: A meta-analysis of randomized controlled trials. Exp Ther Med. 2012; 4: 849-58. doi:10.3892/etm.2012.690.

205. Qi WX, Tang LN, He AN, Shen Z, Lin F, Yao Y. Erlotinib and pemetrexed as maintenance therapy for advanced non-small-cell lung cancer: a systematic review and indirect comparison. Curr Med Res Opin. 2012; 28: 643-50. doi:10.1185/03007995.2012.675880.

206. Lu S, Yu YF. Maintenance Therapy for NSCLC: Consensus and Controversy. Chin J Cancer Res. 2011; 23: 254-8. doi:10.1007/s11670-011-0254-5.

207. Kelly K, Chansky K, Gaspar LE, Albain KS, Jett J, Ung YC, et al. Phase III trial of maintenance gefitinib or placebo after concurrent chemoradiotherapy and docetaxel consolidation in inoperable stage III non-small-cell lung cancer: SWOG S0023. J Clin Oncol. 2008; 26: 2450-6. doi:10.1200/JCO.2007.14.4824.

208. Zhang L, Ma S, Song X, Han B, Cheng Y, Huang C, et al. Gefitinib versus placebo as maintenance therapy in patients with locally advanced or metastatic non-small-cell lung cancer (INFORM; C-TONG 0804): a multicentre, double-blind randomised phase 3 trial. Lancet Oncol. 2012; 13: 466-75. doi:10.1016/S1470-2045(12)70117-1.

209. Cappuzzo F, Ciuleanu T, Stelmakh L, Cicenas S, Szczesna A, Juhasz E, et al. Erlotinib as maintenance treatment in advanced non-small-cell lung cancer: a multicentre, randomised, placebo-controlled phase 3 study. Lancet Oncol. 2010; 11: 521-9. doi:10.1016/S1470-2045(10)70112-1.

210. Patel JD, Hensing TA, Rademaker A, Hart EM, Blum MG, Milton DT, et al. Phase II study of pemetrexed and carboplatin plus bevacizumab with maintenance pemetrexed and bevacizumab as first-line therapy for nonsquamous non-small-cell lung cancer. J Clin Oncol. 2009; 27: 3284-9. doi:10.1200/JCO.2008.20.8181.

211. Belani CP, Goss G, Blumenschein G, Jr. Recent clinical developments and rationale for combining targeted agents in non-small cell lung cancer (NSCLC). Cancer Treat Rev. 2012; 38: 173-84. doi:10.1016/j.ctrv.2011.05.009.

212. Naumov GN, Nilsson MB, Cascone T, Briggs A, Straume O, Akslen LA, et al. Combined vascular endothelial growth factor receptor and epidermal growth actor receptor (EGFR) blockade inhibits tumor growth in xenograft models of EGFR inhibitor resistance. Clin Cancer Res. 2009; 15: 3484-94. doi:10.1158/1078-0432.CCR-08-2904.

213. Falchook GS, Naing A, Hong DS, Zinner R, Fu S, Piha-Paul SA, et al. Dual EGFR inhibition in combination with anti-VEGF treatment: A phase I clinical trial in non-small cell lung cancer. Oncotarget. 2013; 4: 118-27. doi:763 [pii]

214. Wheler JJ, Tsimberidou AM, Falchook GS, Zinner RG, Hong DS, Fok JY, et al. Combining Erlotinib and Cetuximab is Associated with Activity in Patients with Non Small Cell Lung Cancer (including Squamous Cell Carcinomas) and Wild-Type EGFR or Resistant Mutations. Molecular cancer therapeutics. 2013; doi:10.1158/1535-7163.MCT-12-1208.

215. Boutsikou E, Kontakiotis T, Zarogoulidis P, Darwiche K, Eleptheriadou E, Porpodis K, et al. Docetaxel-carboplatin in combination with erlotinib and/or bevacizumab in patients with non-small cell lung cancer. Onco Targets Ther. 2013; 6: 125-34. doi:10.2147/OTT.S42245

216. Herbst RS, Ansari R, Bustin F, Flynn P, Hart L, Otterson GA, et al. Efficacy of bevacizumab plus erlotinib versus erlotinib alone in advanced non-small-cell lung cancer after failure of standard first-line chemotherapy (BeTa): a double-blind, placebo-controlled, phase 3 trial. Lancet. 2011; 377: 1846-54. doi:10.1016/S0140-6736(11)60545-X.

217. Kim ES, Herbst RS, Wistuba II, Lee JJ, Blumenschein GRJr, Tsao A, et al. The BATTLE trial: personalizing therapy for lung cancer. Cancer discovery. 2011; 1: 44-53. doi:10.1158/2159-8274.CD-10-0010. 